\title{
MANAGING FISHING IN THE SUB-ANTARCTIC
}

\author{
by D. G. M. Miller
}

(with seven text-figures and five tables)

\begin{abstract}
Miller, D.G.M. 2007 (23:xi) : Managing fishing in the sub-Antarctic. Papers and Proceedings of the Royal Society of Tasmania 141(1): $121-140$. https://doi.org/10.26749/rstpp.141.1.121 ISSN 0080-4703. CCAMLR Secretariat, P.O. Box 213, North Hobart, Tasmania, 7002 Australia*. Also: Institute for Antarctic and Southern Ocean Studies, University of Tasmania, Sandy Bay, Hobart, Tasmania 7005 Australia. *Address for correspondence.
\end{abstract}

Harvesting of finfish in the sub-Antarctic is briefly described together with an historical account of its management by the international Commission for the Conservation of Antarctic Marine Living Resources (CCAMLR) under the Convention of the same name (CAMLR Convention). The key objectives of the CAMLR Convention are outlined, with emphasis on the procedures adopted by CCAMLR to meet its management objectives through implementation of an ecosystem-based and precautionary approach. Four case studies are presented to illustrate CCAMLR's success as a modern-day and effective marine management organisation. The cases considered are CCAMLR's efforts to: (a) combat Illegal, Unreported and Unregulated (IUU) fishing, (b) mitigate incidental seabird bycatch during longline fishing for toothfish, (c) institute precautionary management of developing fisheries and (d) address environmental protection. In evaluating CCAMLR's actions, emphasis is given to the challenges faced and lessons learnt thereby highlighting the organisation's standing as an example of international best practice in the management of marine living resources on the high seas.

Key Words: CCAMLR management, ecosystem approach, precautionary approach, sub-Antarctic fisheries.

\section{INTRODUCTION}

In its 2006 estimate of global trends for marine fish stock exploitation, the Food and Agricultural Organisation of the United Nations (FAO 2007: 29) (see appendix 1 for acronyms used in this paper) indicated that:

One-quarter of the stocks monitored was underexploited or moderately exploited (3\% and $20 \%$ respectively) and could perhaps produce more. About half of the stocks (52\%) were fully exploited and therefore producing catches that were at, close to, their maximum sustainable limits with no room for further expansion. The other one quarter were either overexploited, depleted or recovering from depletion $(17 \%, 7 \%$ and $1 \%$ respectively) and thus were yielding less than maximum potential owing to excess fishing pressure exerted in the past, with no possibilities in the short to medium term of further expansion and with an increased risk of further declines and need for rebuilding.

The number of fully exploited marine fish stocks (fig. 1) exhibited a consistent and decreasing trend between 1974 and 2006, while the number of under-exploited, or moderately exploited stocks, also declined over the same period. By contrast, the proportion of over-exploited and depleted stocks steadily rose from about $10 \%$ in the mid1970 s to nearly $25 \%$ in 2006.

Such trends have not only resulted in ever-increasing efforts to locate new stocks for exploitation, they have also heightened concerns that unsustainable fishing practices may exert too heavy a price on marine ecosystem productivity as a whole (Pauly et al. 2002). Predominantly negative, this price includes habitat degradation, excessive bycatch, discarding of unwanted catches and ecological consequences that include environmental degradation as well as other harmful effects of harvesting activities. Consequently, Cochrane \& Doulman (2005) conclude that unsustainable fishing practices are the end product of a widespread failure in fisheries management to effectively balance biological and ecological sustainability with socio-economic objectives or expectations.
In the two decades prior to the 1982 negotiation of the United Nations Convention on the Law of the Sea ("LOS Convention"), the international community strove to develop an international legal framework addressing over-exploitation of living marine resources. A major aim of this process was to maintain the health of the ecosystems in which such resources occur (Cochrane \& Doulman 2005). With the LOS Convention's finalisation, impetus and purpose were given to negotiating associated international legal instruments (table 1), particularly to give effect to declarations from the 1992 United Nations Conference on Environment and Development (UNCED), and more recently the 2002 World Summit on Sustainable Development (WSSD).

The legal instruments summarised in table 1 address a wide range of fisheries-related issues. These include biological considerations, conservation concerns, and application of both a precautionary and ecosystem-based (EAF) approach to fisheries management (Cochrane \& Doulman 2005). In particular, the 1995 United Nations Fish Stocks Agreement (UNFSA) (United Nations 1998: 7-37) broadens fisheries management objectives to include mitigation of negative impacts on the marine environment, preservation of marine diversity and maintenance of key marine ecosystem qualities (Edeson et al. 2001).

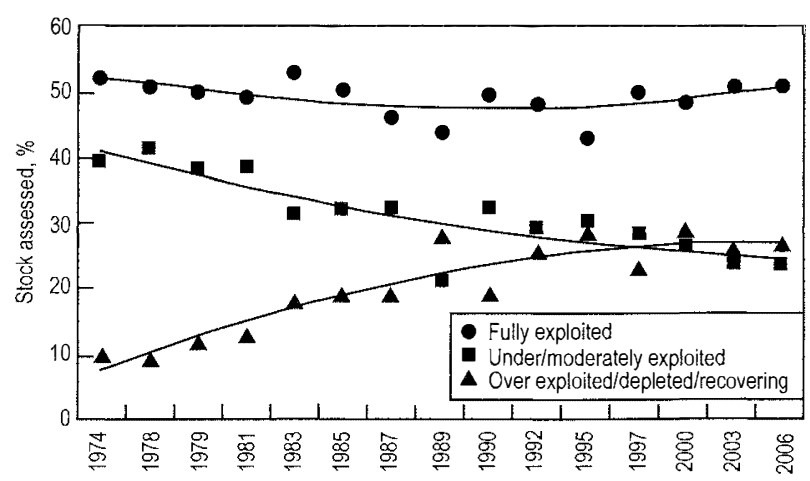

FIG. 1 - Global trends in the state of world marine stocks for the period 1974 to 2006 (after fig. 19 in FA 2007). 
TABLE 1

Some key international agreements directly impacting national and international management of marine living resource exploitation (after Cochrane \& Doulman 2005)

\begin{tabular}{lccc}
\hline Agreement name & $\begin{array}{c}\text { Entry into } \\
\text { force }\end{array}$ & $\begin{array}{c}\text { Purpose } \\
\text { ing }\end{array}$ & $\begin{array}{c}\text { Legal stand- } \\
\text { par- } \\
\text { ties }\end{array}$ \\
\hline
\end{tabular}

Marine Agreements

1982 United Nations Convention on the Law of the Sea (LOS Convention)

1993 FAO Agreement to Promore Compliance with Management Measures by Fishing Vessels on the High Seas (FAO Compliance Agreement)

1995 FAO Code of Conduct for Responsible Fisheries (Code of Conduct)

1995 United Nations Agreement for the Implementation of the United Nations Law of the Sea of 10 December 1982 Relating to the Conservation of Straddling Stocks and Highly Migrating Fish Stocks (UN Fish Stocks Agreement - UNFSA) 2001 Reykjavik Declaration on Responsible Fisheries in the Marine Ecosystem

\section{Related Agreements}

1975 Convention on International Trade in Endangered Species of Wild Fauna and Flora (CITES)

1992 Convention on Biological Diversity (CBD)

Agenda 21 of 1992 UN Conference on Environment and Development (UNCED)
16/11/2004 Primary legal framework for international governance of oceans. Addresses ocean use. Legal basis for conservation, management $\&$ research of marine living resources (Aqorau 2003).

24/4/2003 Better control of fishing vessels on high seas (including mandating auchorization to fish) by strengthening "flag-State responsibility"

$31 / 10 / 1995$ (adopted)

Guidelines consistent with relevant international law, to promote responsible fishing \& fisheries activities $\&$ account for relevant biological, technological, economic, social, environmental \& commercial aspects

11/12/2001 Effective implementation of LOS Convention to prevent overexploitation of high-seas fish stocks (notably highly migratory $\&$ straddling stocks)

4/10/2001 Work collectively towards (Drafted) developing guidelines to incorporate ecosystem considerations into fisheries management

1/7/1975 Ensure international trade in specimens of wild animals \& plants does not endanger their survival

\section{9/12/1993 Sustainable development} by conserving biodiversicy, sustainable use of bio-diversity \& equitable sharing of genetic resources

Programme of action for sustainable development

Voluntary agreement

Legally binding instrument

Legally binding instrument

Voluntary instrument

Legally binding instrument binding instrument

Legally binding instrument

Legally binding instrument
Non-legally

89 Translates Agenda 21 principles. 1995 Jakarta Mandate focuses on integrated management of sustainable marine \& coastal areas/species use.

- Agenda 21 Chapter 17 deals with protection of ocean, all seas, coastal areas \& their living resources. Promotes implementation 1982 LOS Convention \& adoption precautionary approach. CBD was concluded at UNCED.

Update \& reinforcement Voluntary of UNCED action pro- agreement gramme
Consolidates \& reinforces implementation of existing fisheriesrelated instruments. Sets deadlines (where possible) no later than 2015 for EAF applicarion \& fish stock maintenance at MSY 
From an ecosystem perspective, the major challenge to implementing such legally binding and voluntary, or nonbinding, instruments is to balance ecosystem sustainability with human socio-economic expectation through effective marine living resource management. As indicated by the FAO (2003: 14):

The purpose of an ecosystem approach to fisheries is to plan, develop and manage fisheries in a manner that addresses the multiple needs and desires of societies, without jeopardizing the options for future generations to benefit from the full range of goods and services provided by marine ecosystems.

This suggests that the only way to promote food security is through sustainable marine living resource use and the optimisation of ecological, social and economic benefits for current and future generations.

There is little doubt that the scope and potential impact of the various instruments identified in table 1 are profound. However, there are irrefutable challenges to their effective implementation. As Cochrane \& Doulman (2005) assert, many countries appear to be experiencing "instrument implementation fatigue" and this does not bode well for some, if not many, of the key sustainability objectives for effective marine living resource management being met.

Nonetheless, many such considerations have been addressed effectively by the 1980 Convention on the Conservation of Antarctic Marine Living Resources (CAMLR Convention) (CCAMLR 2007) and its attached executive Commission (CCAMLR) nearly a decade and a half before the UNFSA's existence. In fact, implementation of the CAMLR Convention foreshadowed many international advances in fisheries management worldwide during that time and continues to do so (Miller et al. 2004).

This paper outlines how effectively CCAMLR has implemented the CAMLR Convention's ecosystem and precautionary-based management approach in the subAntarctic over the past 25 years. The Convention's entry into force is briefly described and a brief history of finfish fisheries in the sub-Antarctic (north of $60^{\circ} \mathrm{S}$ ) portion of the CCAMLR Area is provided. Examples of various initiatives are used to outline how CCAMLR has gone about its work. Attention is given to the attached administrative processes as well as perceived successes and/or failures. The four case studies show how CCAMLR has addressed Illegal, Unreported and Unregulated (IUU) (see paragraph 3 of FAO 2001 for definition) fishing in the Convention Area, incidental mortality of seabirds during longline fishing, precautionary management of fisheries (particularly for Dissostichus eleginoides (Gill \& Townsend, 1901) - Patagonian Toothfish; "Toothfish") during harvest development, and environmental protection as an element of the organisation's EAF. The outcomes are used to illustrate how CCAMLR has come to perceive its future needs and what has been learned from its past practices. The opinions expressed should be taken as those of the author and do not reflect the collective or official views of CCAMLR.

\section{THE CAMLR CONVENTION}

Much has been written about CCAMLR (e.g., Miller et al. 2004) and it is not intended to provide full details of the organisation's history here. However, a few key features of the CAMLR Convention are worth highlighting.

Following negotiations by the Consultative Parties to the
1959 Antarctic Treaty, the CAMLR Convention entered into force on 7 April 1982. Its basic objective may be summarised as:

Conserving, including rational use of, Antarctic marine living resources south of the Antarctic Polar Front (c. $45^{\circ} \mathrm{S}$ ) through precautionary and ecosystembased management.

The management and conservation principles outlined in Article II of the Convention were without international precedent (Anon. 2002, Miller et al. 2004). They mandate that harvesting and associated activities should be carried out in the CCAMLR Area with due commitment to the following operational considerations:

- Conservation and rational (i.e., sustainable) resource use should be balanced.

- Target species status should be maintained to ensure stable recruitment and stock levels close to greatest net annual biological yield.

- Direct and indirect effects of harvesting should be addressed.

- Ecological relationships between target, dependent and related species should be maintained.

- Depleted populations should be restored.

- Risks of ecosystem changes, not irreversible in 20 to 30 years, should be minimized.

- Management action should take into account anthropogenic effects and environmental change(s).

The balancing of "conservation" and "rational use" in Article II is clearly aimed at ensuring that existing ecological relationships between harvested, dependent and related species are maintained, and that depleted populations are restored to levels at which their biological productivity is greatest. However, the term "rational use" may have various interpretations, especially when an ecological, as opposed to an economic, perspective is assumed. For this reason, CCAMLR has developed a working definition for the term with, inter alia, it being considered to imply that: (a) harvesting of resources is on a sustainable basis and (b) harvesting on a sustainable basis means that harvesting is conducted to ensure that the highest possible long-term yield from the resource, subject to the general conservation principles outlined in paragraph 3 of Convention Article II (CCAMLR 1988 paragraph 139).

Since the CAMLR Convention's entry into force, the ecosystem and precautionary approaches outlined in Article II have both directed and challenged CCAMLR's conservation efforts (Constable et al. 2000, Miller 2000) in the CCAMLR Area. The ecological uncertainties associated with effectively, and fully, implementing the Convention's provisions have necessitated innovative thinking to develop an holistic, scientific and ecologically-based approach to regulating the marine living resources affected by harvesting.

These features distinguish the CAMLR Convention's focus from more customary approaches to fisheries management, such as those based on maximum sustainable yield (MSY) (Butterworth 1986). However, limited knowledge of harvested stock dynamics (especially for Antarctic Krill - Euphausia superba Dana, 1852), as well as equally limited knowledge of functional relationship (s) between harvested and other species (i.e., birds, seals and whales), has tended to impede practical implementation of Article II (Constable 2002). Nevertheless, as shown below, considerable progress has been made and CCAMLR is pre-eminent as an implementable, effective, modern, international fisheries and conservation instrument (Constable et al. 2000). 
The need for supportive science implicit in Article II of the CAMLR Convention, along with an outline of the type of research required, is more explicitly developed in Articles V, VI, VIII and IX. Moreover, Article IX identifies possible management measures (termed "conservation measures" CM) to be applied in meeting Article II objectives. In turn, $\mathrm{CM}$ are required to be based on the best scientific evidence available (Article IX, paragraph 1.(f)) and include, inter alia, setting of catch limits, effort controls, closed areas/ seasons etc.

The ecological considerations in the CAMLR Convention's Preamble result in Article I confining CCAMLR's area of operation to south of the Antarctic Convergence (Antarctic Polar Front) (fig. 2). The Front is perceived as a biogeographic boundary to the species assemblages confined therein (Miller 2000). With the close connection between the CAMLR Convention and the Treaty, the CCAMLR boundary effectively extends the Antarctic Treaty's area of influence north of $60^{\circ} \mathrm{S}$, (i.e., from the continental boundary to the Polar Front) (Anon. 2002). As a consequence, the Convention is required to deal with the legal and jurisdictional implication associated with application of national sovereignty over certain sub-Antarctic islands. While the relevant provisions "freezing" sovereign claims in the Antarctic Treaty Area are addressed in CAMLR Convention Articles III-V, it was necessary to attach a Statement by the Chairman of the Conference on the Conservation of Antarctic Marine Living Resources (Chairman's Statement) to address sovereignty considerations farther north (Miller et al. 2004).

\section{CCAMLR SUB-ANTARCTIC FISHERIES}

Fishing in the CCAMLR Area has predominantly targeted finfish and Antarctic krill (Miller 1991), with finfish harvesting dating from the turn of the last century. Between 1901 and 1903, whalers discovered large concentrations of marbled rockcod (Notothenia rossii Richardson, 1844) around the sub-Antarctic island of South Georgia. For various economic reasons, most notably remoteness from potential markets and greater interest in whaling, this fishery was not fully realised at the time. Subsequent exploratory fishing by Argentina, Norway and Japan between 1930 and 1960 also failed (Miller 1991). The further development, course and fate of finfish fisheries in the CCAMLR Area are described in a number of papers (e.g., Kock 1992, Williams 1995, Williams \& de la Mare 1995, Agnew \& Nicol 1996, de la Mare et al. 1998).

Large-scale harvesting of finfish commenced in 1969/70 in the Southwest Atlantic around South Georgia (CCAMLR Statistical Subarea 48.3) and the following season in the Indian Ocean at the Kerguelen Islands (CCAMLR Statistical Division 58.5.1). The former Soviet Union was heavily involved in both these fisheries until declaration of a 200 mile Exclusive Economic Zone (EEZ) around the Kerguelen Islands largely forced Soviet vessels out of that fishery post1980. Bottom trawling for Toothfish at the Kerguelen Islands continued until the mid-1990s (Duhamel 1993).

Finfish harvesting at South Georgia expanded southward to the South Orkney Islands (CCAMLR Statistical Subarea 48.2) in $1977 / 78$. These more southerly grounds yielded moderate catches for only a few years and by the early $1980 \mathrm{~s}$ were no longer commercially viable (Miller 2000).

Until about 1985, all finfish harvesting in the sub-Antarctic was by trawlers undertaking commercial fishing and was mainly confined to Southern Ocean island shelves (Kock et al. 1985). Since then, finfish harvesting has been more widespread in various CCAMLR Statistical Areas, Subareas and Divisions (table 2, fig. 2).

In the sub-Antarctic per se, historic catches (Kock 1992, 2001) targeted relatively few species in the locations identified in figure 2. As outlined in Fischer \& Hureau (1985), the most notable of these included $N$. rossii, Toothfish, Antarctic Toothfish (Dissostichus mawsoni Norman, 1937) and Mackerel Icefish (Champsocephalus gunnari Lönnberg, 1905). Minor catches were also taken of South Georgia Icefish (Pseudochaenichthys georgianus Norman, 1937), Unicorn Icefish (Channichthys rhinoceratus Richardson, 1844), Blackfin Icefish (Chaenocephalus aceratus Lönnberg, 1906), Humped Rockcod (Lepidonotothen [Notothenia]

TABLE 2

CCAMLR Statistical Areas, Subareas and Divisions where finfish (by species) harvesting has occurred

\begin{tabular}{|c|c|c|}
\hline Location & Common name & Species fished \\
\hline FAO Statistical Area 48 & Atlantic Ocean Sector & \\
\hline Subarea 48.1 & South Shetlands & $\begin{array}{l}\text { Notothenia rossii, Chaenocephalusaceratus, Chaenodraco wilsoni, Champ- } \\
\text { socephalus gunnari, Lepidonotothen [Notothenia] gibberifrons }\end{array}$ \\
\hline Subarea 48.2 & South Orkneys & $\begin{array}{l}\text { N. rossit, C. aceratus, C. gunnari, Pseudochaenichthys georgianus, } \\
\text { Dissostichus eleginoides, L. gibberifrons, Lepidonotothen [Notothenia] } \\
\text { squamifrons }\end{array}$ \\
\hline Subarea 48.3 & South Georgia & $\begin{array}{l}\text { N. rossit, D. eleginoides, C. gunnari, Electrona carlsbergi, C. aceratus, } P \text {. } \\
\text { georgianus, N. gibberifrons, N. squamifrons, Patagonotothen guntheri }\end{array}$ \\
\hline Subarea 48.4 & South Sandwich & D. eleginoides \\
\hline FAO Statistical Area 58 & Indian Ocean Sector & \\
\hline Subarea 58.6 & Crozet \& Prince Edward & D. eleginoides \\
\hline Subarea 58.7 & Prince Edward & D. eleginoides \\
\hline Subarea 58.4 .2 & & C. wilsoni, Dissostichus mawsoni \\
\hline Division 58.4 .3 & BANZARE \& Elan Banks & D. eleginoides D. mawsoni \\
\hline Division 58.4 .4 & Ob \& Lena Banks & D. eleginoides, L. squamifrons \\
\hline Division 58.5 .1 & I. Kerguelen & N. rossii, D. eleginoides, C. gunnari, L. squamifrons \\
\hline Division 58.5 .2 & Heard \& Macquarie & D. eleginoides, C. gunnari \\
\hline
\end{tabular}




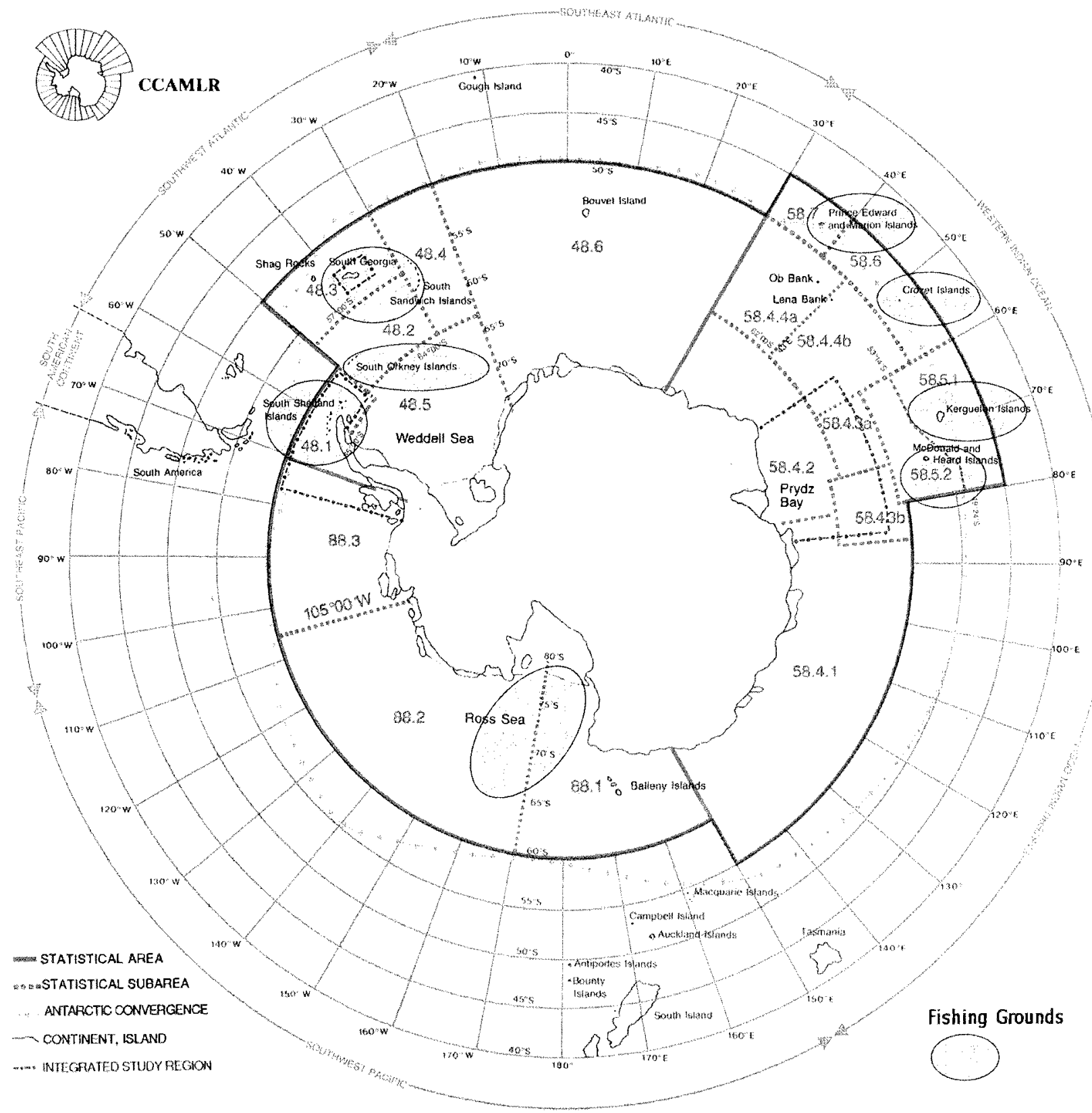

FIG. 2 - The CCAMLR Area (modified from CCAMLR 1997-2006). The location of finfish fishing grounds in the CCAMLR Area are shown, with fishing on Antarctic Toothfish (Dissostichus mawsoni) in CCAMLR Statistical Subareas 88.1 and 88.2 included for completeness.

gibberifrons Lönnberg, 1905), Grey Notothenia or Rockcod (Lepidonotothen [Notothenia] squamifrons Günther, 1880), Günther's Notothenia (Patagonotothen guntheri Norman, 1937), Subantarctic Lanternfish (usually identified as Electorna carlsbergi Tåning, 1932) and the Spiny Icefish (Chaenodraco wilsoni Regan, 1914). From time to time, bycatch included $G$. gibberifrons, various icefish species (family Channichthyidae), skates/rays (Raja georgiana Norman, 1938, Bathyraja spp. and Macourus spp.), and in recent years sharks (Somniosus spp.).

Prior to the CAMLR Convention, finfish harvesting in the CCAMLR Area was largely a "boom and bust" affair, similar to Antarctic whaling (Miller 2000). This entailed the successive discovery, exploitation and depletion of each new target stock over progressively shorter time scales. During the late 1970 s and early 1980s, the severe depletion of demersal fish stocks (most notably $N$. rossii) was followed in the second half of the latter decade by harvesting of benthopelagic species such as Toothfish, species with variable year class strengths (C. gunnari) and mesopelagic species such as $E$. carlsbergi.

By the early 1990s, CCAMLR CM prohibited directed fishing on most finfish species (e.g., N. rossii in particular) or had introduced total allowable catches based on some objective assessment of stock yield (Constable et al. 2000). Other management measures were also introduced and included, inter alia, closed areas/seasons as well as measures to regulate new and exploratory fisheries.

Both the South Orkneys (Subarea 48.2) and Antarctic Peninsula (Subarea 48.1) were closed to directed finfish harvesting in 1993. Economic considerations effectively ended the E. carlsbergi fishery at the end of the 1991/92 
season (Miller 2000) while other fishing grounds, such as the $\mathrm{Ob}$ and Lena Seamounts, were effectively closed from the mid-1990s onwards.

Two other major developments characterised the finfish harvest in the CCAMLR Area. During the 1988/89 season, the former Soviet Union introduced a deepwater longline fishery for Toothfish around South Georgia (Subarea 48.3) (CCAMLR 1989 paragraph 104). Previously, the species had predominantly been taken as by-catch in various trawl fisheries; a point well-illustrated by the 4200- and 8300 tonne longline catches in $1988 / 89$ and $1989 / 90$ respectively compared with the 5000 -tonne accumulated catch over the previous ten years (1977 to 1988). The development of this longline fishery triggered the emergence of a substantial Toothfish IUU fishery.

Between 1972/73 and 2005/06, a total of 3.66 million tonnes of finfish were taken in the sub-Antarctic portion of the CCAMLR Area (CCAMLR 1990-2006). Of this total, about 2.16 million tonnes were taken in the West Atlantic (Area 48), with 1.83 million tonnes (85\%) caught around South Georgia (Subarea 48.3). Of the 1.5 million connes caughe between 1969/70 and 2005/06 in the Indian Ocean, 0.83 million tonnes $(55 \%)$ are attributable to the Kerguelen Islands environs (Division 58.5.1).

\section{CCAMLR MANAGEMENT PROCESS}

The functions of many regional management organisations rely on the effective administration and synchronisation of some key institutional elements. In CCAMLR's case, these elements comprise CCAMLR itself, Contracting Parties, the Scientific Committee, other subsidiary bodies and the Secretariat.

\section{Commission}

Various CAMLR Convention Articles outline the conditions for becoming a Commission Member (Article VII), CCAMLR's legal character (Article VIII), its various functions and associated matters (Articles IX-XI), and the attached conditions for consensus-based decision-making (Article XII).

In outlining conditions for CCAMIR membership, Article VII.(2) distinguishes between Contracting Parties to the CAMLR Convention and Members of the Commission. For the latter, only founding Contracting Parties were immediately eligible for Commission membership (Article VII.(2).(a)). Parties acceding to the Convention pursuant to Article XXIX are entitled to become Commission Members while engaged in active research on, or harvesting of, the marine living resources to which the Convention applies (Article VII.(2).(b)).

Under Article IX, CCAMLR is politically "responsible" for giving effect to the CAMLR Convention's objective and principles ser our in Article II. This is achieved by facilitating relevant research and by promulgating $\mathrm{CM}$, with Article IX.(2) identifying the substance of the latter. Decision-making on CM and other matters of substance is by consensus (Article XII) and limited to Commission Members only (i.e., those parties that have met the requirements of Article VII.(2)). Article IX.(6) sets the conditions for CM implementation.
The application of $\mathrm{CM}$ in waters over which the existence of state sovereignty is recognised by all Contracting Parties is qualified by the Chairman's Statement (see above). The procedures for applying national measures as opposed to CCAMLR-agreed CM are set out in paragraph 3 of this Statement.

Finally, key emphasis is placed on, and guidance given to, CCAMLR co-operation with other relevant international organisations, both inter-governmental and non-governmental (Article XXIII).

\section{Contracting Parties}

Contracting Party and Member responsibilities are outlined in Articles XXI and XXII. Together with national responsibilities for implementing CM (Article XXI.(1)), Contracting Parties are mandated to cooperate in establishing a system of observation and inspection to promote the CAMLR Convention's objective and to ensure that its provisions are met (Article XXIV). This requirement and the annually published list ofCM in force (i.e., CCAMLR 1997-2006) lay the foundation for the monitoring, control and surveillance (MCS) system through which CCAMLR regulates relevant activities in the CCAMLR Area. Over the years, the CM themselves have evolved to provide essential interpretive and administrative elements for the execution of Contracting Party responsibilities.

\section{Scientific Committee}

The Scientific Committee, established by CAMLR Convention Article XIV, serves to provide the Commission with the best scientific information available (Article IX.(1). (f)) for the latter's work. The Committee's membership is limited to Commission Members (Article XIV.(2)) and it serves as a forum for consultation and cooperation in the collection, study and exchange of relevant information to promote scientific reseatch (Article XV.(a)). Its activities are outlined in Article XV.(2) and include regular assessment of stock status and trends, analyses of harvesting effects, both direct and indirect, and the provision of such assessments, analyses etc. to the Commission as required.

\section{Other subsidiary bodies}

CCAMLR relies on input from two other standing committees established under Rule 36 of its Rules of Procedure. The Standing Committee for Implementation and Compliance (SCIC) develops advice on MCS, compliance enforcement and application of the Observation Scheme and Inspection System. The Standing Committee on Administration and Finance (SCAF) provides advice on general administrative (e.g., functioning of the Secretariat) and budgetary (as per Article XIX as well as the Commission's Financial and Staff Regulations) (CCAMLR 2007 - Footnote 2) matters.

Various specialist scientific Working Groups have been established under Article XVI.(3) and Scientific Committee Rule of Procedure 13. These are essentially forums for expert consultation and detailed scientific debate. The most notable groups currently include the Working Group for Fish Stock Assessment (WG-FSA), the Working Group for Ecosystem Monitoring and Management (WG-EMM), 
the Working Group on Assessment Methods (WG-SAM) and the ad hoc Working Group on Incidental Mortality Associated with Fishing (WG-IMAF). All under take routine analyses required by the Scientific Committee and serve as the first step in preparing appropriate advice for the Commission's consideration and to inform its decisionmaking processes.

\section{The Secretariat}

Finally, in establishing its headquarters in Hobart, Australia, (Article XIII) and the post of Executive Secretary (Article XVII), the CAMLR Convention provides for the day-to-day administration of CCAMLR. Under the Executive Secretary's leadership, the Secretariat archives data submitted by the Contracting Parties and circulates relevant information amongst the Parties. It also publishes and translates documents related to the Commission's work (table 3) while undertaking various other functions as directed by CCAMLR. In conformity with Article XIII.(3), the Secretariat now serves as the venue for CCAMLR annual meetings.

Over the past 25 years, CCAMLR has evolved an annual cycle for its essential business. As illustrated in figure 3 , the key outputs from this process comprise fishery regulations in the form of CM and depend on each administrative component outlined above operating effectively. CCAMLR's annual, iterative and progressive nature has meant that outputs have become more complicated and sophisticated over time, a point illustrated by the breadth, and subject depth, of CM both past and present.

Consistent with the objectives of Article II of the CAMLR Convention, CM adopted by CCAMLR to date have been directed at both fisheries regulation (table 4) and environmental protection (table 5). As such, the unique status and international trend-setting nature of the following CCAMLR CM and resolutions are particularly noteworthy, along with the issues that they strive to address. These include:

- incidental mortality of birds and mammals during fishing (CM 25-02 and 25-036 - table 4, R 22/XXV; table 5)
- notification and procedures aimed at regulating new and exploratory fisheries in the absence of information (CM 21-01 and 21-02; table 4)

- Contracting Party, including nationals, compliance (CM 10-06 and 10-08;- table 4)

- Non-Contracting Parties compliance and cooperation enhancement (CM 10-07, R 14/XIX, 19/XXI, 24/XXIV and 25/XXV; table 4)

- general environmental protection (CM 22-04, 22-05, 26-01, 32-09 and 32-18; table 5).

The CCAMLR achievements most worth noting have been the Catch Documentation Scheme (CM 10-05) (Sabourenkov \& Miller 2004) to monitor trade in IUUcaught Toothfish, along with CM addressing fisheries notification, authorisation and at-sea monitoring procedures (CM 10-02, 21-01, 21-02 and 10-04) (Miller et al. 2004). General environmental protection measures (particularly CM 26-01 and 22-05) have also been significant. The amalgamation of good environmental practice for fishing vessels into a single measure (CM 26-10) is revolutionary while an interim prohibition on bottom trawling (CM 22-05) is both significant and pre-emptive.

The successful implementation of such measures does much to counter the criticism that CCAMLR's consensusbased decision-making is too slow. They also provide clear justification for the organisation being recognised as the pre-eminent leader in the world of fisheries management (Small 2005); a status that is largely attributable to the scope, effect and innovation of CCAMLR's management approach and mandate implementation (Miller et al. 2004, Willock \& Lack 2006).

\section{CCAMLR CASE STUDIES}

Four case studies are reviewed here to illustrate some of CCAMLR's major achievements in setting up a management approach consistent with the principles and objectives outlined in Article II of the Convention.

TABLE 3

CCAMLR annual publications

\begin{tabular}{|c|c|c|c|c|}
\hline Publication & $\begin{array}{c}\text { Fre- } \\
\text { quency }\end{array}$ & Medium & Language & Nature \\
\hline Commission Report & Annual & $\begin{array}{l}\text { Hardcopy } \\
\text { Web copy }\end{array}$ & $\begin{array}{l}\text { English, French, } \\
\text { Russian, Spanish }\end{array}$ & Meeting Report Commission \& subsidiary bodies \\
\hline Scientific Committee Report & Annual & $\begin{array}{l}\text { Hardcopy } \\
\text { Web copy }\end{array}$ & $\begin{array}{l}\text { English, French, } \\
\text { Russian, Spanish }\end{array}$ & Meeting Report Scientific Committee \& subsidiary bodies \\
\hline $\begin{array}{l}\text { Schedule of Conservation } \\
\text { Measures in Force }\end{array}$ & Annual & $\begin{array}{l}\text { Hardcopy } \\
\text { Web copy }\end{array}$ & $\begin{array}{l}\text { English, French } \\
\text { Russian, Spanish }\end{array}$ & Texts Binding CM \& Non-Binding Resolutions in Force \\
\hline Statistical Bulletin & Annual & $\begin{array}{l}\text { Hardcopy } \\
\text { Web copy }\end{array}$ & $\begin{array}{l}\text { English, French, } \\
\text { Russian, Spanish }\end{array}$ & Aggregated Fisheries Statistics \\
\hline CCAMLR Science & Annual & $\begin{array}{l}\text { Hardcopy } \\
\text { Web copy }\end{array}$ & English & Scientific journal \\
\hline
\end{tabular}




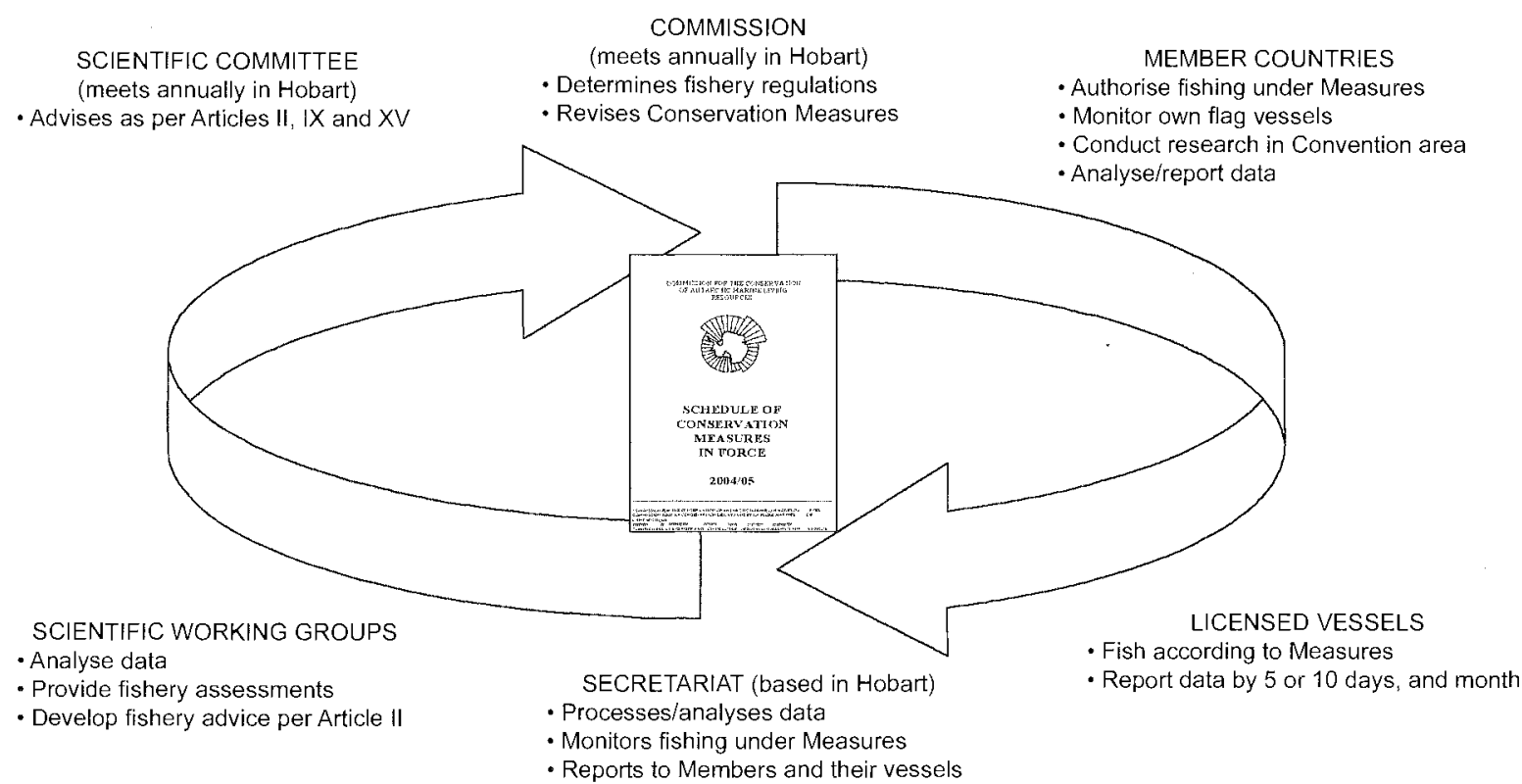

FIG. 3-Annual cycle of CCAMLR management and associated actions (see text for details).

TABLE 4

\section{Some CCAMLR regulatory Conservation Measures (CM) and Resolutions (R) (CCAMLR 1997-2006)}

Type of measure
Fishery Regulatory Measures
Prohibit directed Toothish fishing in absence CM
Advance notification of new fisheries.
Advance notification \& conduct of exploratory Toothfish fisheries, including data collection \& research plans
Fishing effort limitation
Reporting catch, effort \& biological data, including reporting of fine-scale data
Placing international scientific observers on vessels targeting Toothfish

Reducing seabird mortality during longline \& trawl fishing

\section{Flag State Measures}

Contracting Party licensing \& inspection obligations for fishing vessels under their flag in Convention Area At-sea inspections of Contracting Party fishing vessels

Marking of fishing vessels \& fishing gear

Deployment satellite-based VMS on vessels (except krill fishery) licensed by CCAMLR Members

to fish in Convention Area

Toothfish Catch Documentation Scheme

\section{Port State Measures}

Port inspections vessels landing Toothfish to ensure compliance CCAMLR CM

Scheme promoting compliance by Contracting Party vessels with CM

Scheme promoting compliance by Non-Contracting Party vessels with CM

Scheme promoting compliance by Contracting Party nationals with CM

\section{Resolutions}

Harvesting stocks occurring both within, \& outside, Convention Area, with due respect to CCAMLR CM Implementation Catch Documentation Scheme by Acceding States \& Non-Contracting Parties

Use of ports not implementing Toothfish Catch Documenration Scheme

Application of VMS in Catch Documentation Scheme

Use of VMS \& other measures to verify CDS catch data outside Convention Area,

$$
\text { especially in FAO Statistical Area } 51
$$

Harvesting of Toothfish outside areas of Coastal State jurisdiction adjacent to Convention Area in FAO Statis- R 18/XXI

tical Areas $51 \& 57$

Flags of non-compliance

Electronic Catch Documentation Scheme for Dissostichus eleginoides

Non-Contracting Party Cooperation Enhancement Program

Combating IUU fishing in Convention Area by Non-Contracring Party flag vessels

CM 32-09
CM 21-01

CM 21-02, 41-01

CM 41-04 to $41-07$ CM 23-01, 23-02,

23-03, 23-04 \& 23-05

CM 41-01 \& others

Scientific Observer

Scheme

CM 25-02, 25-03

CM $10-02$

System of Inspection

CM 10-01

CM 10-04

CM 10-05

CM 10-03

CM 10-06

CM 10-07

CM 10-08

R 10/XII

R 14/XIX

R 15/XIX

R 16/XIX

R 17/XX 
TABLE 5

Some CCAMLR environmental protection Conservation Measures (CM) and Resolutions (R)

Type of measure $\quad$ Measure

General Environmental Protection

Interim prohibition of deep-sea gillnetting

CM 22-04

Interim restrictions on bottom trawling gear use in high seas areas within

CM 22-05

Convention Area, $2006 / 07$ to $2007 / 08$

General environmental protection during fishing

CM 26-01

Area Closure/Protection

Areas closed to directed fishing for Finfish in Subareas 48.1, 48.2

Areas closed to directed fishing except under specific CM

CM 32-02, 32-03

CM 32-09

Fishing Season

Definition

32-01

Limit fishing to specific fishing seasons

CM 41-02.(5)*, 41-03.(6), 41-04.(3), 41-05.

(4), 41-06.(3), 41-07.(3), 41-08.(3), 41-09.

(3). $41-10 .(3) /(4), 41-11 .(4), 42-01 .(5)$,

$42-02 .(6), 51-01 .(5), 51-02 .(4), 51-03 .(2) \&$

$52-01 .(6)$

Site Protection

Procedures for, \& protection of, CEMP (CCAMLR Ecosystem Monitoring CM 91-01 to 91-03

Programme) Sites

Species Protection

Prohibition of directed fishing for certain species

Shark conservation

Incidental mortality mitigation

Bycatch regulation

CM 32-04 to 32-17

CM 32-18

CM 25-02, 25-03 \& relevant section of numerous fishery regulation $\mathrm{CM}$

CM 33-01, 33-02, 33-03, 41-01.(4), 41-02.

(6-8), 41-05.(7), 41-06.(4), 41-07.(4),41-08.

(4) 41-11.(7), 42-01.(6), 42-02.(7) \& 52-01.

(7)

\section{$\mathrm{R} 22 / \mathrm{XXV}$}

CM 10-01

CM 22-01, 22-02 \& 22.03

CM 25-02.(2), 25-02.(3), 25-03.(6) \& 25-03.

(5)

CM 24-02 \& 24-03

CM 25-02.(4) \& 25-03.(2)

R 23/XXIII

R 20/XXII

* References in parentheses are to specific CM paragraphs (CCAMLR 1997-2006)

\section{Combating IUU fishing}

Undoubtedly, IUU fishing poses a serious challenge to effective ocean governance and hence continues to preoccupy a number of important international forums such as the FAO (FAO 2001), the Committee for Fisheries (COFI) (COFI 2005) and the recent Inter-Ministerial Task Force on IUU Fishing (HSTF 2006). In its broadest implications, IUU fishing not only compromises stock sustainability, but also undermines food security and serves to deny economic advancement (MRAG 2005)

CCAMLR has always recognised that compliance enforcement poses a serious challenge to the effective implementation of its CM. The problem is compounded by the Convention's area size, $\left(35\right.$ million $\left.\mathrm{km}^{2}\right)$, remoteness and open access, particularly in respect of the high seas (Molenaar 2001). These concerns, together with growing interest in economically valuable Toothfish stocks during the early to mid-1990s, meant that CCAMLR was forced to face the challenge posed by IUU fishing as a matter of priority.

Until the emergence of large-scale IUU fishing, CCAMLR MCS measures tended to be based on conventional approaches (e.g., input and output controls) common to many fisheries enforcement agencies (Rayfuse 1998). These relied heavily on application of Flag State jurisdiction and fulfilment of Port State responsibilities. Table 4 shows that the bulk of CCAMLR MCS measures rely on prohibiting fishing 
without due authorisation (CM 10-02), monitoring fishing location using vessel monitoring systems (VMS) (CM 10-04) and requiring notification of vessel movements. These were expanded to include at-sea (System of Inspection) and in-port inspections (CM 10-06 and 10-07) as well as comprehensive fisheries data reporting (Miller et al. 2004).

Expansion of Toothfish longline fisheries in the early to mid-1990s (fig. 4) moved CCAMLR to realise that traditional MCS alone is unlikely to be effective in combating a persistent and expanding IUU fishery (Agnew 1999). As indicated, this was a problem compounded by both CCAMLR area's size and the mix of jurisdictional conditions therein. The latter includes Coastal State jurisdiction, Flag State jurisdiction, and Non-Contracting Party involvement, as well as high seas rights under the LOS Convention (Molenaar 2001).

IUU fishing not only undermines CCAMLR CM, it also violates principles set out in other international fisheries agreements, such as UNFSA Article 18 on Flag State duties, as well as the obligations of Non-Members, or Non-Participants, in regional fisheries arrangements (UNFSA Article 17) and generally (LOS Convention Articles 116-119).

Being economically valuable and in some demand, Toothfish has attracted significant prices internationally over the past decade. As fishable stocks are located within and outside the CCAMLR Area, IUU fish caught in the CCAMLR waters have been difficult to track through the global trade cycle. IUU operators have benefited by being able to trade fish free from any attached regulatory restrictions and in relative obscurity with the origin of catches being hard to determine (Agnew 1999, Green \& Agnew 2002, Sabourenkov \& Miller 2004). Therefore, CCAMLR began developing measures in 1998 to improve monitoring of Toothfish landings, the subsequent access of associated products to international markets for fish caught by its members and by voluntary participating parties, in the Convention Area as well as in waters under the coastal state jurisdiction of members. This initiative culminated in the Toothfish Catch Documentation Scheme (CDS) entering into force on 7 May 2000

Development of the CDS has been comprehensively documented elsewhere (e.g., Agnew 1999) and its provisions are clearly detailed in CM 10-05 (table 4). However, in addressing a number of key, and in many cases relatively novel, principles, the CDS strives to track global Toothfish trade and to restrict the access of IUU-caught Toothfish to international markets. It also enables CCAMLR to identify the origin of Toothfish entering the markets of all CDS Parties and to better determine if Toothfish are caught in the Convention Area consistent with CCAMLR CM. The most pervasive feature of the CDS is that it allows total Toothfish removals to be estimated, an essential prerequisite for stock assessment purposes. As updated from table 5 in Miller et al. 2004, the key underlying principles of the CDS:

- address CCAMLR Contracting and Non-Contracting Party fishing alike

- promote non-discriminatory, fair and transparent practices

- are practical and rapidly implementable

- apply to fishing both inside and outside the CCAMLR Area (i.e., recognise the "transboundary" nature of Toothfish distribution)

- encourage CCAMLR Non-Contracting Party participation
- include validation and verification procedures to raise confidence in the information produced

- outline the obligations of all participants

- prohibit entry of Dissostichus spp. into world markets in the absence of verified catch documents

- determine if Dissostichus spp. harvesting in the CCAMLR Area is consistent with CCAMLR CM;

- require Flag State authorisation for Dissostichus spp. harvesting both inside and Outside the CCAMLR Area

- set conditions for the sale of Dissostichus spp. seized or confiscated through enforcement action

- promote Flag State, Port State and importing State cooperation

- facilitate estimation of total Dissostichus spp. removals for global catch and stock assessment purposes.

Despite the fact that it complements similar global initiatives, Miller et al. (2004) have stressed that the CDS was never intended as a stand-alone measure, but rather as an integral component in a suite of CCAMLR measures to combat IUU fishing. Undoubtedly, however, it is still a major CCAMLR achievement in countering such fishing. Not only are evaluations of its effectiveness encouraging (Sabourenkov \& Miller 2004, Willock \& Lack 2006), the CDS is unique in scope and application and became fully operational within a relatively short period (less than two years). Its overall coverage now extends to more than $90 \%$ of the global Toothfish trade (Miller et al. 2004).

Using the CDS, participating parties have been able to deny Toothfish landings and/or shipments in the absence of attached documents. Such absence constitutes a rebuttable presumption aimed at triggering enforcement action. The CDS has also improved estimates of global Toothfish catch levels while highlighting incidents where malpractice and fraudulent documentation are occurring. Such qualities were instrumental in setting up two of the largest and most successful prosecutions under the Lacey Act for infringement of CCAMLR CM arising from illegal Toothfish trade into the United States (Oritz 2005, Anon 2006a). Together with evidence that the CDS's introduction has made trading in IUU-caught fish less profitable, it also appears to be having the desired effect of restricting market access to IUU-caught product (Green \& Agnew 2002).

With the various improvements that have been drafted into CM 10-05 since it was first adopted, the CDS has also allowed CCAMLR to promote a multi-lateral and global approach to combat Toothfish IUU fishing. This has largely been possible since the CDS is globally applicable, while application of other CCAMLR CM is essentially limited to within the CCAMLR Area and to Contracting Parties alone. Furthermore, the CDS' implementation is entirely consistent with the provisions of UNFSA Articles 7, 8 and 17 as these relate to compatibility of measures, cooperation and Non-Contracting Parties.

Since it strives to minimise discrimination against any particular State, there is little doubt that the CDS' efficacy benefits from both enhanced international cooperation and also from a semblance of coherence with World Trade Organization requirements (Larson 2000). Further support for this view is evidenced by the clear aim of broadening the CDS' application globally through closer cooperation between CCAMLR and Parties to the Convention on International Trade in Endangered Species (CITES) via improved cooperation and information exchange between the two organisations (CCAMLR 2002 paragraphs $10.72-10.75)$. 


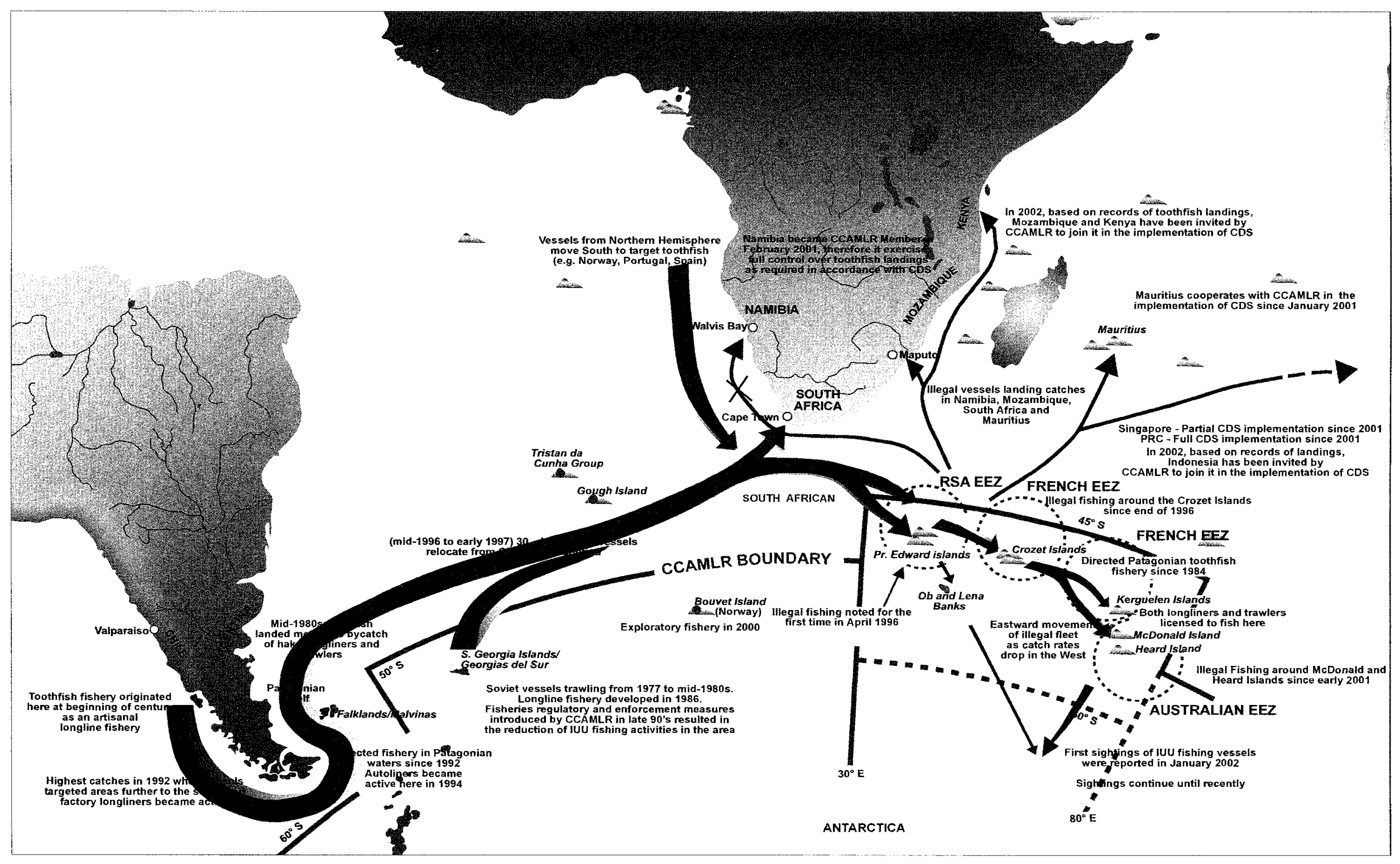

FIG. 4-Development of IUU fishing in the CCAMLR Ared (updated from fig. 4 in Miller et al. 2004). 
Despite the CDS' obvious benefits, the CM illustrated in table 4 clearly show that the former does not stand alone in combating IUU fishing. As a "package", combined with effective Coastal State action (e.g., see table 10 in Miller et al. 2004), application of the CDS, in combination with more traditional MCS measures, has provided positive indications of effective IUU deterrence. This conclusion is supported by a discernible decline in estimates of Dissostichus spp. IUU catch levels for recent years (fig. 5). Although such a decline could reflect diminishing Toothfish stocks, Baird (2006) remains optimistic that CCAMLR's enforcement efforts to counter IUU fishing have been positive when combined with vigorous Coastal State action, particularly in the sub-Antarctic Indian Ocean.

Finally, there is little doubt that the CDS provides the additional dimension of dealing with third-party involvement, where such a party is a State that is neither a Flag State fishing in the CCAMLR Area nor a CCAMLR Contracting Party. Consequently, Flag State enforcement is augmented. It has also extended responsibilities similar to those of CCAMLR Contracting Parties to other States participating in the Scheme (Miller et al. 2004). The latter is particularly important as it distinguishes between various IUU "actors" in terms of identifying flag, port, export and import State responsibilities. Such information is likely to be helpful in identifying those actually benefiting from IUU activities through facilitating identification of Toothfish end-users and trade locations (Vidas 2004).

\section{Seabird incidental mortality}

The 1999 FAO International Plan of Action for Reduction of Incidental Catch of Seabirds in Longline Fisheries (IPOASeabirds) (FAO 1999) indicates concern at (i) the negative consequences of such mortality on threatened seabird stocks, and (ii) possible impact(s) on fishing productivity and profitability.

The need to address incidental mortality of Antarctic marine living resources arising from harvesting activities is clearly alluded to in Article II.(3).(c) of the CAMLR Convention in terms of minimising the risk of irreversible ecosystem changes. By 1984, CCAMLR had requested members recotd the number, species and, where appropriate, age, size, sex and reproductive status of any birds or marine mammals taken incidentally during fishing operations (CCAMLR 1986 paragraph 42).

Initially CCAMLR estimated the number of albatrosses (mostly sub-Antarctic species) being killed annually at 45 000 in tuna longline (i.e., pelagic) fisheries outside the Convention Area (Croxall 1990). Although this was thought to be a conservative estimate, it was sufficiently high to substantiate claims that the serious declines observed in Albatross populations breeding in the CCAMLR Area could be attributed to such fishing activity (SC-CAMLR 1989, paragraph 6.7, SC-CAMLR 1990, paragraph 7.3).

With the introduction of demersal longlining for Toothfish around South Georgia in 1989, CCAMLR voiced its concern based on experiences with longlining elsewhere (CCAMLR 1989, paragraph 24). These focused on the potentially high levels of seabird mortality associated with longline fishing that arise when birds are hooked and drowned while feeding on baited hooks during line setting (particularly in daylight hours). At South Georgia, the risks were compounded by the relative proximity of fishing grounds to land-based breeding sites of threatened seabird species, predominantly albatrosses and petrels, at crucial times (SC-CAMLR 1989, paragraph 6.7, SC-CAMLR 1990, paragraph 7.3, Kock 2001).

Noting Australia and Japan's successes in reducing seabird bycatch in tuna longline fisheries (CCAMLR 1990, paragraph 5.3), CCAMLR initially mandated deployment of "tori poles" or "scare" lines to deter birds from taking

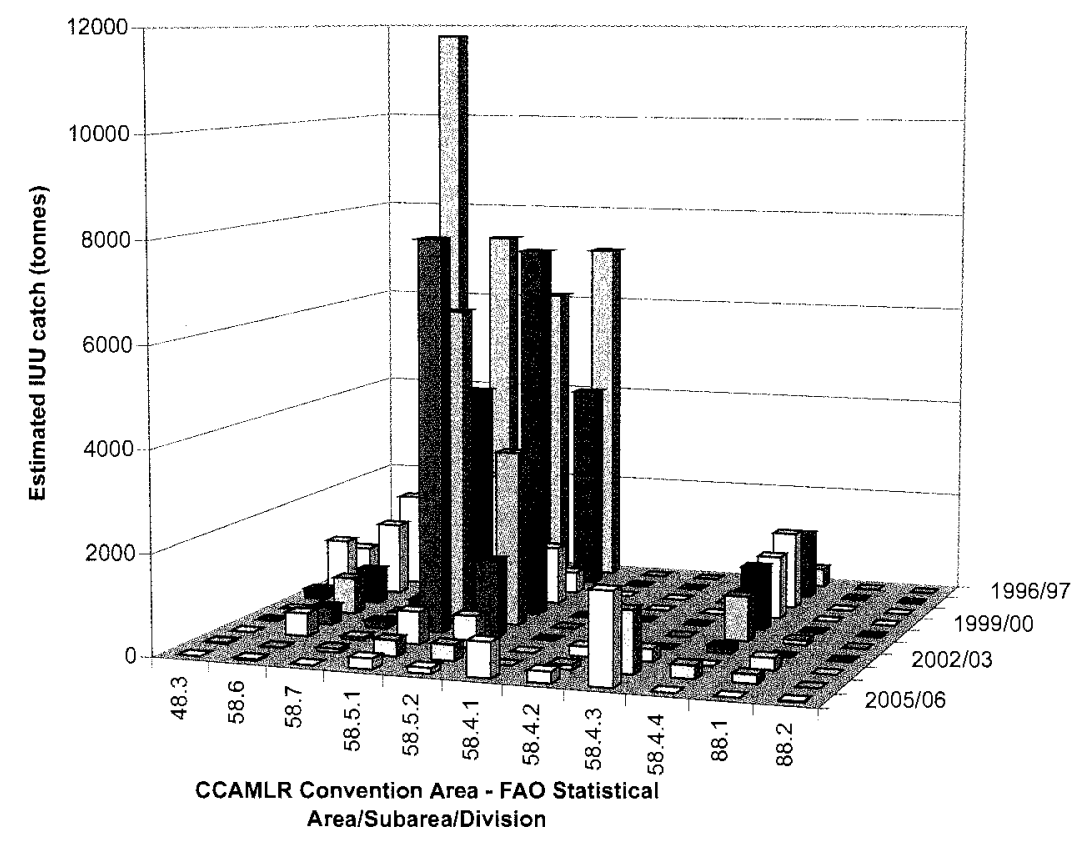

FIG. 5-IUU catch estimates for the CCAMLR Area by statistical SubarealDivision for seasons 1996/97 to 2005/06 (updated from fig. 3 in Sabourenkov \& Miller 2004). 
baited hooks close to the surface, particularly during daytime line-setting. Combined with night-setting, these simple measures significantly reduce seabird catch and formed a basis for future CCAMLR seabird mitigation measures (see below). Attached economic benefits included reduction of bait loss and a consequent improvement in fishing efficiency (SC-CAMLR 1990, paragraph 7.5).

CCAMLR therefore became the first international organisation to institute comprehensive incidental seabird mortality mitigation measures. In 1989, the adoption of Resolution 5/VIII (CCAMLR 1989, paragraphs 107 and 108 ) aimed to minimise incidental seabird mortality. This was followed by CM 29/X the next year, which with substantial revisions (see table 4 in Miller et al. 2004) has endured as CM 25-02 (CCAMLR 1997-2006). CCAMLR, in the form of ad hoc WG-IMAF, continues to estimate potential seabird by-catch in proposed new and exploratory fisheries as well as monitoring by-catch of both seabirds and mammals in trawl fisheries (e.g., CCAMLR 2002, paragraph 6.22). A decade after CCAMLR's initial efforts to countenance mitigation of seabird incidental mortality, the bulk of its experiences were incorporated into the IPOA-Seabirds mentioned above.

Over the past seven years, seabird bycatch in CCAMLRregulated longline fisheries has been reduced to almost insignificant levels. Since 1997 such levels have been negligible in Subarea 48.3, low in the South African EEZ in Subareas 58.6 and 58.7 and non-existent in Subareas 88.1 and 88.2. In 2006, seabird bycatch levels (fig. 6) in the CCAMLR Area were the lowest on record and for the first time an Albatross catch of zero was reported for the regulated longline fishery (CCAMLR 2006, paragraph 5.6). This success is largely attributed to compliance with CCAMLR by-catch measures and to delaying commencement of fishing until the end of the breeding season for most albatross and petrel species (Kock 2001).

Nevertheless, CCAMLR remains concerned that IUU fishing in the CCAMLR Area, combined with seabird by-catch in fisheries to the north, is still the major threat to many seabird populations in the Southern Ocean (e.g.,
CCAMLR 2002, paragraph 6.8). Estimates of potential by-catch levels associated with IUU fishing in each of the past nine years are also shown in figure 6 . Since many albatrosses, Giant Petrels and White-Chinned Petrels breeding in the CCAMLR Area are declining at rates where extinction is a possibility, CCAMLR continues to view this as a compelling incentive for strict measures to combat IUU fishing (Kock 2001).

The observed decline in the estimated take of birds by the IUU fishery since the 2002/03 season, however, is difficult to explain. In the absence of clear information on the extent of mitigation being practised by that fishery, it is only possible to conclude that interactions between birds and the fishery have declined. This could be attributed to the IUU fishery having moved its location to areas more remote from bird feeding grounds; an explanation enhanced by recent trends in the IUU fishery, particularly in the Indian Ocean, over the past year or so (see figs 4,5).

While no single mitigating measure is likely to eliminare all seabird mortality during longlining, CCAMLR's experience has indicated that it is crucial that lines be set to minimise visual detection, and feeding, by foraging birds on bait close to the surface. In CCAMLR's case this has been achieved by fishers complying fully with straightforward measures; namely regulation of offal discharge, streamer line deployment and night-setting. Nevertheless, refining, and enhancing compliance with, specified line-weighting regimes (especially for the Spanish longline system) remains a priority (CCAMLR 2002, paragraph 6.11.(i)). Lineweighting requirements for the Norwegian Autoline system were incorporated into CM 25-02 in 2003 (table 4).

CCAMLR also continues to encourage development of appropriate line-weighting requirements (CCAMLR 2002, paragraph 6.16.(iii)), while striving to improve seabird bycatch mitigation in the CCAMLR Area. In addition, it has drawn members' attention to potential modifications to provide facilities for underwater line-setting on new, or replacement, vessels (paragraph 7.197 in Annex 5 of SCCAMLR 2000). Finally, CCAMLR continues to receive advice from the Scientific Committee, based on ad hoc

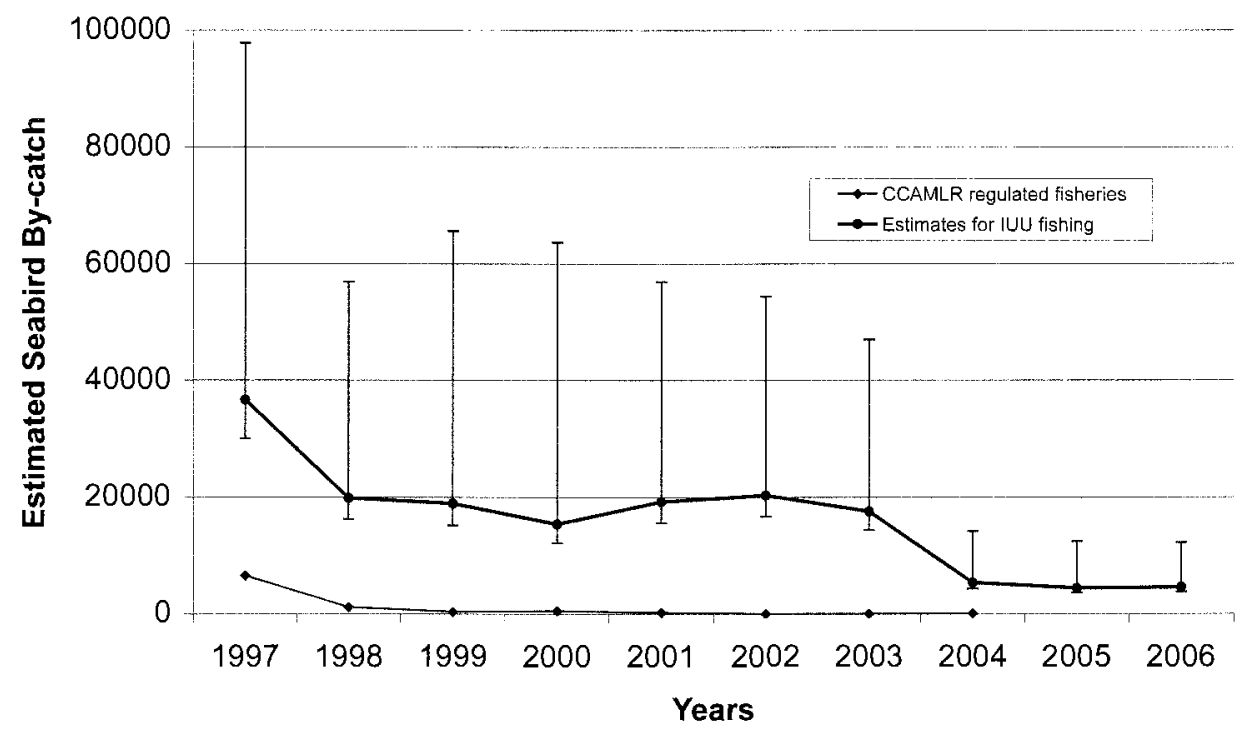

FIG. 6 - Estimated seabird bycatch in CCAMLR regulated and unregulated (IUU) longline fisheries in the CCAMLR Area (updated from fig. 3 in Miller et al. 2004). 
WG-IMAF's annual reviews of seabird bycatch mitigation measures. It also strives to keep abreast of international best practice while actively promoting cooperation with other management organisations (e.g., as per Resolution 22/XXV - CCAMLR 1997-2006).

\section{Precautionary management of fisheries}

Ideally, commercial fisheries development should not outstrip the information necessary to manage the sustainable, and scientifically defensible, exploitation of the stocks being targeted (Butterworth 1999). This allows for comparisons to be made of stock status before and after exploitation begins, with management action modified to maintain a target stock level. However, new fisheries are often exploited - even over-exploited - well in advance of essential management information becoming available, or even being collected. In this context, the precautionary elements of Article II of the CAMLR Convention "strive to minimise the risk of irreversible change(s) induced by effects of harvesting on target, and dependent, stocks".

On advice from its Working Group for the Development of Approaches to Conservation of Antarctic Marine Living Resources (WG-DAC) in 1989 (CCAMLR 1989, Annex. $\mathrm{E}$ ), and from the Scientific Committee a year later (SCCAMLR 1990, paragraph 8.7), CCAMLR sought to address management of new fisheries in the CCAMLR Area. For definitional purposes, a "new" fishery was considered to be a fishery on a species using a particular fishing method in a Statistical Subarea for which: (i) information on distribution, stock abundance, demography, potential yield and identity from comprehensive research/surveys or exploratory fishing have not been submitted to CCAMLR; or (ii) catch and effort data have never been submitted to CCAMLR; or (iii) catch and effort data from the two most recent seasons in which fishing occurred have not been submitted to CCAMLR (CCAMLR 1997-2006).

It was recognised that development of new fisheries "should be directly linked with elaborating scientific advice and management measures" to ensure that CCAMLR does not compromise its efforts to meet the objectives of Convention Article II (CCAMLR 1990, paragraph 9.3).

CCAMLR also accepted the Scientific Committee's advice (SC-CAMLR 1990, paragraph 289 in Annex 5) that certain vital information is essential for assessing the potential yield of a new fishery and that such information should be considered before full commercial development of a fishery begins so that any development may be kept consistent with Article II objectives (CCAMLR 1990, paragraph 9.4). This advice required prior notification of new fisheries as a basis for developing management measures consistent with conditions set out in both Articles II and IX of the CAMLR Convention (CCAMLR 1990, paragraph 9.5).

The considerations outlined in the previous paragraph led to adoption of CM 31/X in 1991 (CCAMLR 1991, paragraph 10.3). The key features of this measure were the need for prior notification of any new fishery and the fulfilment of attached conditions for its implementation. In its current form, CM 31/X now stands as CM 21-01 (CCAMLR 1997-2006), which expressly recognises that fisheries should be managed from the time that they are initiated. It also mandates pre-notification of the intent to commence a new fishery as well as sets conditions for collecting information on target and dependent species, and for limiting initial fishing catch and/or effort.

In 1993, CCAMLR concluded that following a year of fishing a new fishery becomes an "exploratory" fishery. CM 65/XII (now CM 21-02) was thus adopted in the same year to address fisheries that are no longer new, but for which critical management information remains unavailable (CCAMLR 1993, paragraph 8.39 and updated table 2 in Miller et al. 2004) to:

- Evaluate distribution, abundance, and demography of the target species, leading to an estimate of the fishery's potential yield

- Review the fishery's potential impacts on dependent and related species

- Allow the Scientific Committee to formulate and provide advice to CCAMLR on appropriate harvest catch levels, as well as effort levels and fishing gear, where appropriate. Under CM 21-02, an "exploratory" fishery is one previously defined as "new" under CM 21-01. It continues to be defined as "exploratory" until the key conditions outlined above have been met (CCAMLR 1997-2006). Both "new" and "exploratory" fisheries are subject to rigid notification and review procedures before CCAMLR authorises fishing subject to a full assessment of stock yield having been undertaken. All other fisheries are therefore considered either to be "closed" (i.e., not specifically open to fishing as new or exploratory fisheries, or as closed by specific CCAMLR CM), or are classed as no longer being exploratory (i.e., since essential management and catch/ effort information have become available).

The CCAMLR approach enshrined in CM 21-02 allows precaution to be continuously applied to exploratory fisheries and provides for collection of essential data to underpin full assessment of the fishery and $\operatorname{stock}(s)$ concerned. It also attempts to reduce the potential for irreversible change(s) to the ecosystem in which the fishery takes place.

A key attachment to CM 21-02 outlines a Data Collection Plan. Along with similarly attached Research and Fishery Operational Plans, this allows the Scientific Committee to undertake an annual review of developments to form the basis for its advice on prosecution of the fishery in question.

Since the late $1990 \mathrm{~s}$, numerous notifications for new and exploratory (especially exploratory) Dissostichus spp. fisheries in the CCAMLR Area have been received but not activated (see fig. 2 in Miller et al. 2004). This situation initially concerned CCAMLR (CCAMLR 2004, paragraphs 9.4-9.6), but has been ameliorated over the past two years by introduction of a recoverable fee for activated notifications introduced in 2005 (CCAMLR 2005, paragraph 3.12).

Additional to area-based regulatory measures setting catch limits and other restrictions (e.g., fishing season and effort limitations) for notified fisheries, CCAMLR has developed a single general measure (CM 41-01) to regulate exploratory Dissostichus spp. harvesting. CM 41-01 therefore contains some important elements to outline, inter alia, procedures to spread fishing effort, both temporally and spatially, data reporting requirements, bycatch limits for non-target fish species and mandatory deployment of CCAMLR International Scientific Observers designated in accordance with the Scheme of International Scientific Observation set up under Article XXIV of the Convention (CCAMLR 1997-2006). It also outlines provisions for seabird incidental mortality mitigation, bycatch regulation, environmental ptotection and data reporting. 
CM 41-01 has undergone a number of significant modifications The most notable of these are summarised in table 3 of Miller et al. (2004). The introduction of small-scale research units (SSRU) in 2000 required that Toothfish exploratory fisheries operators collect data in a more scientifically rigorous way and that catch and effort be spread over a number of fine-scale areas (see fig. 1 in the 2006 version of CCAMLR 1997-2006). The SSRU approach is aimed at improving data collection on Dissostichus spp. distribution and abundance from areas where information is limited or absent. It also aims to minimise the risk of unacceptable and irreversible damage being inflicted on targeted stocks, as well as associated (i.e., bycatch) species, in a manner that allows insight into the key ecological processes likely to be involved.

The SSRU approach has been expanded to provide for additional gathering of scientifically-based information in the form of a tagging program for Dissostichus spp. (Annex 41-01/C of CM 41-01 - table 4) (CCAMLR 1997-2006). Such information is to be used in developing knowledge on stock dynamics and distribution in circumstances where such knowledge is generally lacking.

Following introduction of the above regime, CCAMLR then attempted to improve definition of when fisheries are no longer exploratory (i.e., when data for management purposes are sufficient to allow a fully regulated fishery). The subsequent debate focused on the need to review relationships between various stages of fisheries development to ensure, in the management context, a coherent progression from exploitation of an unexploited resource through various developmental phases to full commercial harvesting (CCAMLR 1997, paragraph 10.4). After several iterations, a Unified Regulatory Framework (URF) for CCAMLR fisheries was produced (SC-CAMLR 2000, paragraphs 7.27.20). In complementing existing regulatory requirements of relevant CM, the URF not only mandates prior notification of intended fishing, but also the establishment of Research and Fishery Operational and Data Collection Plans.

Another key URF element requires preparation of a basic reference document ("Fishery Plan") to be maintained by the CCAMLR Secretariat for each fishery in the CCAMLR Area. The Fishery Plan summarises information on the fishery concerned and includes a list of all attached regulatory requirements. Plans enable the Scientific Committee to develop advice on whether assessment of a particular fishery is required and/or possible. It also allows CCAMLR to formulate $\mathrm{CM}$ based on the total available information for the fishery concerned. To date, Fishery Plans have been developed for Krill, C. gunnari and Toothfish in Area 48 (South-West Atlantic).

As a general and precautionary principle, CCAMLR has agreed that until new information is received, no further advice on notified, but un-prosecuted fisheries should be developed (CCAMLR 2001, paragraph 10.3). Furthermore, measures such as CM 32-09 (table 4) clearly establish the principle that areas remain closed to fishing in the absence of specific measures to regulate harvesting.

\section{Environmental protection}

The provisions of sub-paragraphs 3.(b) and 3. (c) of CAMLR Convention Article II identify relatively broad objectives for ecosystem and precautionary management in the CCAMLR Area (Miller 2000, 2002). In this context, CCAMLR's approach over the past two decades has been comprehensively summarised by, amongst others, Constable (2002), Constable et al. (2000), Everson (2002) and Miller (2002). However, and as emphasised by Miller et al. (2004), a key point to note is that this approach has been guided by an operationally effective interpretation of Article II to account for pre-agreed key, and coherent, principles. As updated from tables 7 and 8 in Miller et al. (2004), these may be divided into underlying principles and an attached operational pro forma. The former comprises recognition that:

- Conservation includes rational use. The latter is subject to different interpretations, inter alia,

(a) harvesting of resources is on a sustainable basis

(b) such harvesting is conducted to ensure that the highest possible long-term yield can be taken from a resource, subject to the general principles of conservation in Article II of the Convention being met

(c) the cost-efficiency of harvesting and management should be given due weight.

- Harvesting and/or associated activities should be conducted according to accepted conservation principles.

- As a general principle, the ecosystem(s) should be maintained in a state where:

(a) present and future options are preserved, which requires preventing decreases in harvested population size to levels below which stable recruitment and the maintenance of ecological relationships between harvested, dependent and related populations are ensured

(b) risk(s) of irreversible change or long-term adverse effects of harvesting and/or associated activities should be minimised

(c) wherever applicable, both consumptive and nonconsumptive resource use should be given due weight and should be maximised on a continuing basis.

- Management decisions should account for uncertainty associated with imperfect knowledge and should be "precautionary" (i.e., conservative) in the absence of complete knowledge.

- Measures conserving resources should be formulated and applied to avoid wasteful use of other resources.

- Planned and actual resource use should be preceded, and accompanied, by surveys to assess resource potential, the monitoring of resource status and associated analysis of ancillary data.

The CCAMLR operational pro forma outlined has applied four key actions to achieve these principles:

- development of operational objectives to articulate target status for relevant ecosystem aspects

- development of methods to assess ecosystem status

- elaboration of decision rules for adjusting harvest controls to account for differences between assessments and agreed objectives

- development of methods to address uncertainty [including ecosystem functional ("Physical World") uncertainty] to facilitate the reaching of scientific consensus.

At the risk of some repetition, this section will focus on the efforts of CCAMLR to minimise harvesting effects on the sub-Antarctic environment and to better understand the environment in which the marine living resources for which it is responsible are found.

Table 5 shows that CCAMLR has adopted various measures to manage fishing and other CCAMLR-related activities to account for general environmental and, by implication, ecosystem "concerns". Such measures are consistent with the requirements of other international 
instruments such as the 1991 Madrid Protocol to the Antarctic Treaty on Environmental Protection and the 1973/78 International Convention for the Prevention of Pollution from Ships (MARPOL 73/78), especially its Annex. 5. They also conform with general provisions outlined in Article IX. (3). (b) and (c) of the CAMLR Convention.

In 2006, CCAMLR amalgamated most of the environmental provisions from a number of $\mathrm{CM}$ into a single measure, CM 26-01 (table 5) (CCAMLR 1997-2006). This not only served to streamline reference to such measures, but also provided a more unified approach to addressing the environmental effects of harvesting activities that CCAMLR is trying to avoid. CM-26-01 thus regulates garbage disposal and attempts to minimise marine pollution by fishing vessels through dealing with disposal of plastic materials (CM 26-01 paragraphs 1 to 4) and prohibiting offal dumping as well as the discharge of a number of potential marine pollutants (e.g., fuel oil and sewage) in high latitude areas south of $60^{\circ} \mathrm{S}$ (paragraph 5 in CM-26-01). CM 26-01 also prohibits translocation of live poultry and mandates removal of non-consumed poultry products south of $60^{\circ} \mathrm{S}$ (paragraph 6 in CM 26-01). It is not hard to envisage such regulations being extended throughout the CCAMLR Area especially CM 26-10 paragraph 6. This particular provision could prove an important prerequisite for minimising risk of avian influenza spreading into the CCAMLR Area.

Probably more relevant to the sub-Antarctic, CCAMLR has recently adopted two measures directly aimed at limiting the impact of environmental damage arising from potentially unsuitable fishing practices. In keeping with growing international concerns about such practices (United Nations 2006, paragraphs 58-60), CM 22-04 and 22-05 provide for an interim-prohibition on deep-sea gillnetting and restriction on bottom-trawling in the high seas respectively.

Table 5 also shows that various other CM close particular areas to fishing generally (CM 32-02, 32-03 and 32-09) or limit fishing to specific seasons (CM 41-02-41-11, 42-01/ o2, 43.2 to 43-04, 51-01 to 51-03 and 61-01). Combined with prohibition of directed fishing on certain species (CM $32-04$ to 32-17) or general invocations aimed at conserving selected species (e.g., sharks - CM 32-18), such measures have a positive environmental effect as they not only strive to protect fished or related species at key times, they also afford general protection to the marine environment (e.g., CM 32-02 and 32-03) since any potential environmental consequences of harvesting are minimised. Coupled with bycatch regulation (CM 25-02/03, 33-02/03, 42-01/42.02, 43-02 to 43-04 and 52-01), CCAMLR species protection measures strive to mitigate indirect harvesting effects.

An additional suite of CM deals with the way that different kinds of fishing gear are to be used in the Convention Area. These require that gear be marked for identification purposes (CM 10-01) and set out conditions for gear construction (CM 25-02 and 25-03) and testing (CM 24.02 and 24-03). As such, mesh size regulations (CM 22-01 to 22-03) not only set net construction standards, they also serve to protect parts of any targeted stocks as a function of body size.

Therefore, and from a general environmental awareness perspective, CCAMLR stands as one of the few, if not only, organisations of its kind to have attempted to address specifically fishing vessel safety standards. While the CM concerned outline operational safety requirements (e.g., minimum lighting standards during fishing - CM 25-02 and 25-03), they are also more general in nature. In this regard, Resolution 20/XXII is globally unique in linking the licensing of vessels fishing in high latitudes to a minimum ice classification requirement.

Finally, the CCAMLR Ecosystem Monitoring Programme (CEMP) was initiated in 1984 (Agnew 1997, Miller 2002) to improve CCAMLR's understanding of potential interactions between fishery, harvested species and the environment. CEMP's major purpose is to monitor key life-history parameters of selected dependent, or "indicator", species likely to be affected by the availability of harvested species. The monitoring sites are afforded special protection by various CM (CM 91-01 to 91-03).

Using CEMP information, CCAMLR is actively engaged in developing a management procedure to formally account for ecosystem considerations, and environmental influences, in its decision-making (Constable 2002). The procedure being followed is illustrated in figure 7 and it can be seen that it strives to give effect to the pro forma approach outlined above as it addresses the need (updated from Miller et al. 2004) to:

- apply correct and timely decisions to facilitate fulfilment of Article II conservation principles

- undertake monitoring of sufficient power so that harvest controls do not negatively affect dependent predators

- allow sufficient time to detect and rectify harvest-induced changes in the ecosystem within two or three decades as mandated by Article II

- refine assessments of harvested stock yield to account for new estimates of key demographic parameters and by dividing precautionary yield into small-scale management units (SSMU) of appropriate scale to improve predictive power and spread any risk of irreversible ecosystem changes

- develop operational objectives for non-harvested species to account for uncertainties associated with ecosystem function and dynamic relationships amongst predators, and particularly between predators and prey.

The management procedure itself comprises a set of rules to adjust harvest levels based on objective assessment so that the management objectives illustrated in figure 7 have a high probability of being fulfilled. The state of the ecosystem in question is observed through monitoring (i.e., via CEMP). Regular assessments are therefore undertaken to account for uncertainty associated with ecosystem functioning as well as potential relationships between monitoring and that ecosystem, including its physical environment. This particular initiative remains a key priority for CCAMLR in terms of fulfilling the requirements of Article II of the CAMLR Convention.

\section{CONCLUSIONS}

CCAMLR as an organisation has learnt much during its 25 year existence. To reflect on these lessons, Australia and Chile hosted a CCAMLR Symposium in April 2005 to provide a forum for frank and open discussion of CCAMLR's past, present and future (Anon. 2005). One of the symposium's key products was the following list of issues and ideas (based on information provided in paragraphs 16.6 to 16.18 of CCAMLR 2005 and Anon. 2005) for further consideration by the participants, CCAMLR, its Member States and others. The list was grouped into two main categories, with each category requiring specific topics to be addressed, objectives to be met or actions to be taken: 


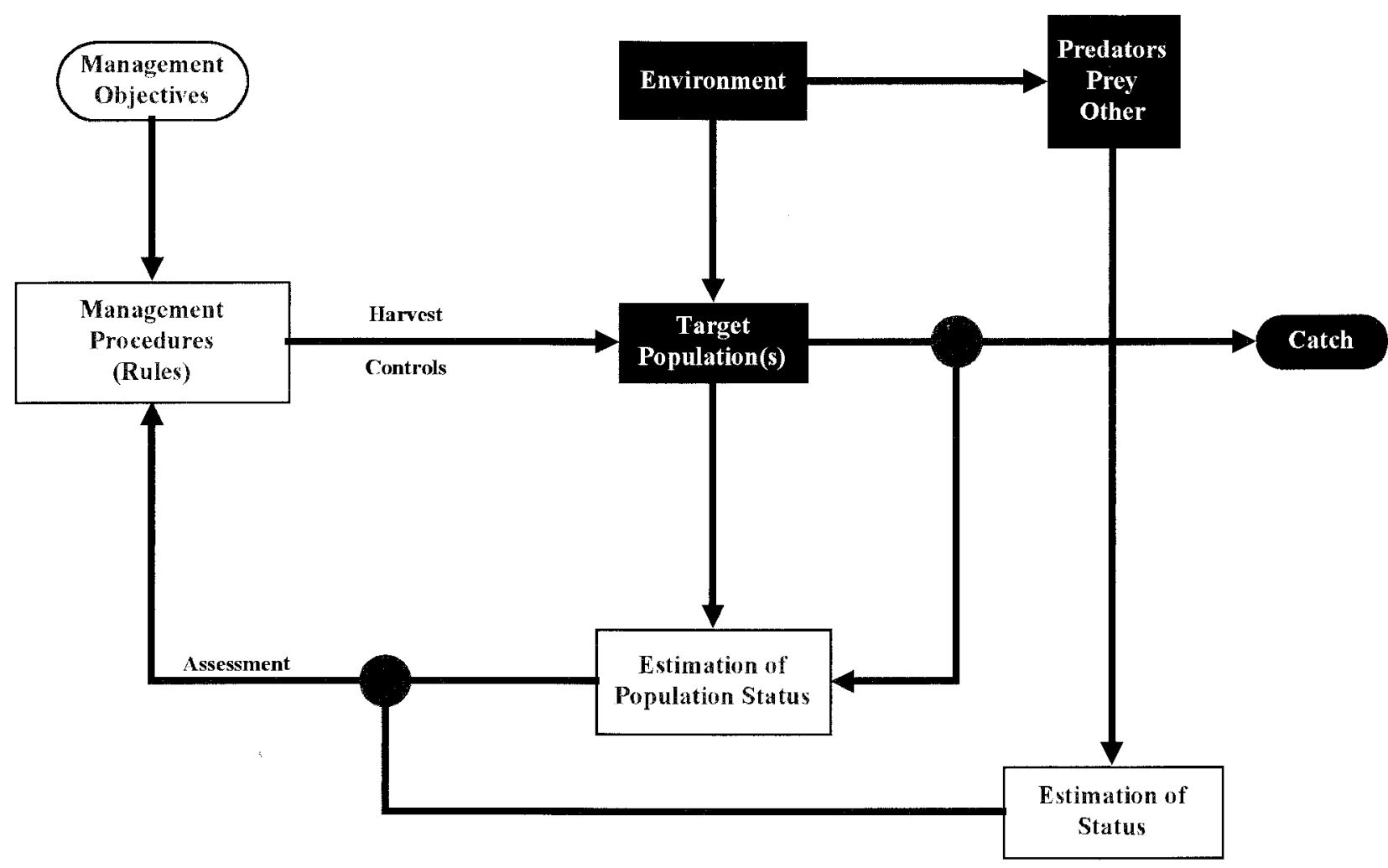

FIG. 7 - CCAMLR's ecosystem management approach to address the effects of harvesting on dependent and related species (see text for details) (adapted from Constable 2002 with permission).

- Threats to be faced

expectations and resources mismatched

- conflicting objectives

- legitimate stakeholder participation

- uncertainty concerning key management factors or parameters

- equity issues

- lack of standardized ecological value system to benchmark management initiatives

- insufficient human and/or logistic capacity (particularly for MCS).

- Topics for co-operation and/or action and coordination

- sustainable marine living resources

- environmentally "healthy" areas

- effective institutions

- common standards (e.g., for assessment or management action)

- exchange of relevant information

- robust legal provisions (especially for CM)

- effective MCS (especially on-water enforcement) objective and robust science.

The various topics were discussed in detail and were seen to warrant future priority action (CCAMLR 2005, paragraphs 16.10-16.18). A number of the items listed for future action, and in CCAMLR (2005, paragraphs 16.12 and 16.5), have since been addressed. Particular achievements include initiatives to address bioregionalisation of key species as a precursor to establishing objectively defined marine protected areas (MPAs) (paragraphs 6.1-6.6 in CCAMLR 2006) and CM 22-04 and 22-05 aimed at addressing the United Nations' call for action on destructive fishing practices. Further work has also been identified to use CEMP data in developing models for sub-dividing the Area $48 \mathrm{krill}$ catch limit between SSMU (paragraph 4.9 in CCAMLR 2006) and to improve information flow between CCAMLR and other regional fisheries management organisations on matters of mutual concern (paragraphs 16.59-16.66 in CCAMLR 2006). These actions are not only precedent-setting in their own right, they indicate openness and transparency to support the notion that CCAMLR continually strives to improve its performance in the execution of its mandate. As already indicated (Small 2005), these are qualities that serve to demonstrate that CCAMLR leads other Regional Fishery Management Organisations ("RFMOs") in assessing its own performance through introspective, dynamic, flexible and reflective review. To this end CCAMLR has a standing item on its annual agenda to consider implementation of the Convention's objectives. This particular item spawned the CCAMLR Symposium outlined above.

CCAMLR has learnt a number of other key lessons over the past 20 years (1986-2006), namely:

- Good and tractable science is essential for addressing large management uncertainties.

- Proactive management and pre-agreed decision rules minimise potential conflict.

- Management action should be realistic, dynamic, flexible and monitorable.

- At-sea scientific observation is an extremely valuable source of essential fisheries information.

- Wide MCS is essential for effective compliance enforcement (especially in respect of IUU fishing).

- Formal processes to address new and exploratory (i.e., "developing") fisheries are essential for effective management and the accrual of necessary data.

- CCAMLR cannot solve all its problems alone (especially 
in respect of any transboundary effects), so mandating good cooperation with RFMOs of similar interest or mandate

- IUU fishing compromises everything by requiring a substantive commitment of valuable, and often limited, resources as a counter as well as by compounding uncertainty.

As indicated here and supported by Constable (2006), CCAMLR:

- Demonstrates the attributes of both an RFMO as well as wider conservation responsibilities (see also CCAMLR-XXI/BG/13 and CCAMLR 2002, paragraphs 15.1-15.2).

- Has instituted a precautionary approach to fisheries management.

- Stands alone internationally as the leading regional management organisation in terms of benchmarking best-practice for an ecosystem approach to managing fishing activities in waters outside national jurisdiction. CCAMLR has not achieved the above alone, and it has continually strived to cooperate with neighbouring organisations on matters of common interest such as seabird incidental mortality (e.g., International Convention for the Conservation of Atlantic Tuna [ICCAT]) and transboundary management of Toothfish (Convention on the Conservation of Fisheries Resources in the South East Atlantic [SEAFO]). It also encourages Non-Contracting Parties to become involved in its work, such as through the CDS and Resolution 24/XXIV (table 4), to ensure that CCAMLR's conservation efforts benefit from full information input in determining the global extent of Dissostichus spp. harvesting.

This kind of cooperation indicates the far-sightedness of Articles X, XI and XXIII of the CAMLR Convention. It is perhaps fitting that 25 years after the Convention entered into force the intent of these particular articles remain relevant. Along with other CCAMLR Convention provisions, most notably Article II, the examples presented here reinforce CCAMLR's unique standing as a leader in ocean governance efforts globally.

Finally, it must be reiterated that IUU fishing stands as the most serious threat to the efforts of CCAMLR and other RFMO (Anon. 2006b) to manage the sustainability of the marine living resources for which they are responsible. Not only is CCAMLR hindered by the size and remoteness of the CCAMLR Area in addressing this threat, the involvement of Non-Contracting Parties and the need to deploy scarce resources to address IUU fishing in all its facets have compounded the challenge faced by the Commission and its members (Vidas 2004, Baird 2006). Consequently, the effective elimination of IUU fishing has come to rest on improving global cooperation as much as on any single measure or management strategy (COFI 2005). Nevertheless, as suggested by Willock \& Lack (2006), and based on its past performance highlighted in this paper, CCAMLR remains the obvious leader to follow.

\section{REFERENCES}

Agnew, D.J. 1997: Review: The CCAMLR Ecosystem Monitoring Programme. Antarctic Science 9: 235-242.

Agnew, D.J. 1999: The illegal and unregulated fishery for Toothfish in the Southern Ocean and the CCAMLR Catch Documentation Scheme. Marine Policy 24: 361-374.

Agnew, D.J. \& Nicol, S. 1996: Marine disturbances - commercial fishing. In Hoffman, E.E. \& Quetin, L.B. (eds): Foundations for Ecological Research West of the Antarctic Peninsula. Antarctic Research Series 70: 417-435.

Anon. 2002: Handbook of the Antartic Treaty System, Ninth Edition. United States Department of State, Washington, D.C.: $1012 \mathrm{pp}$.

Anon. 2005: CCAMLR Symposium. Volume 1: Report of the Chairs. Australian Antarctic Division, Kingston, Tasmania, Hobart. 32 pp. http://www.aad.govau/MediaLibrary/ asset/MediaItems/ml_386914445949074_CCAMLR\%20 Symposium\%20Volume\%201.pdf

Anon. 2006a: Uruguayan Company and Corporate Executive Plead Guilty and are Sentenced for Illegal Dealings in Chilean Seabass. Press Release, US District Attorney's Office, Southern District of Florida, http://www.usdoj.gov/usao/ As/PressReleases/061 113-01.html.

Anon. 2006b: Ministerial Declaration: Conference on the Governance of High Seas Fisheries and UN Fish Stocks Agreement - Moving from words to action. Canadian Department of Foreign Affairs, Ottawa, Canada: 5 pp. http://www.dfo-mpo.gc.ca/fgc-cgp/declaration_e.htm.

Aqorau, T. 2003: Obligations to protect marine ecosystems under international conventions and other legal instruments. In Sinclair, M. \& Valdimarsson, V. (eds): Responsible fisheries in the marine ecosystem. FAO and Wallingford, CABI Publishing, Rome: 25-40.

Baird, R.J. 2006: Aspects of Illegal, Unreported and Unregulated Fishing in the Southern Ocean. Springer, Dordrecht, Netherlands: $286 \mathrm{pp}$.

Butterworth, D.S. 1986: Antarctic ecosystem management. Polar Record 23: 37--47.

Butterworth, D.S. 1999; Taking Stock: Science and Fisheries Management. Inaugural Lecture Series, University of Cape Town, Cape Town, South Africa. Series 12: 12 pp.

CCAMLR 1986: Report of the Fifth Meeting of the Commission (CCAMLR-V). CCAMLR, Hobart, Australia: $85 \mathrm{Pp}$.

CCAMLR 1988: Report of the Seventh Meeting of the Commission (CCAMLR-VII). CCAMLR, Hobart, Australia: 121 pp.

CCAMLR 1989: Report of the Eighth Meeting of the Commission (CCAMLR-VIII). CCAMLR, Hobart, Australia: 135 Pp.

CCAMLR 1990: Report of the Ninth Meeting of the Commission (CCAMLR-IX). CCAMLR, Hobart, Australia: $123 \mathrm{pp}$.

CCAMLR 1990-2006: Statistical Bulletin. CCAMLR, Hobart, Australia. http://www.ccanlr.org/pu/e/e_pubs/sb/voll8. hem.

CCAMLR 1991: Report of the Tenth Meeting of the Commission (CCAMLR-X). CCAMLR, Hobart, Australia: $101 \mathrm{pp}$.

CCAMLR 1993: Report of the Twelfth Meeting of the Commission (CCAMLR-XII). CCAMLR, Hobart, Australia: 133 pp.

CCAMLR 1997: Report of the Sixteenth Meeting of the Commission (CCAMLR-XVI). CCAMLR, Hobart, Australia: $152 \mathrm{pp}$.

CCAMLR 1997-2006: Schedule of Conservation Measures in Force. CCAMLR, Hobart, Australia. http://www.ccamlr.org/ $\mathrm{pu} / \mathrm{e} / \mathrm{e} \_$pubs $/ \mathrm{cm} / \mathrm{drt} . \mathrm{htm}$.

CCAMLR 2001: Report of the Twentieth Meeting of the Commission (CCAMLR-XX). CCAMLR, Hobart, Australia: 186 pp.

CCAMLR 2002: Report of the Twenty-First Meeting of the Commission (CCAMLR-XXI). CCAMLR, Hobart, Australia: 205 pp.

CCAMLR 2004: Report of the Twenty-Third Meeting of the Commission (CCAMLR-XXIII). CCAMLR, Hobart, Australia: $169 \mathrm{pp}$.

CCAMLR 2005: Report of the Twenty-Fourth Meeting of the Commission (CCAMLR-XXIV). CCAMLR, Hobart, Australia: 189 pp.

CCAMLR 2006: Report of the Twenty-Fifth Meeting of the Commission (CCAMLR-XXV)[Preliminary Version]. CCAMLR, Hobart Australia. Retrieved 8 January 2007 from: hrtp://www.ccamlr.org/prm/cc/mem06/eng/eprepub.pdf . 
CCAMLR 2007: Basic Documents and Associated Texts. CCAMLR, Hobart, Australia. Retrieved 10 January 2007 from: http:// www.ccamlr.org/pu/e/e_pubs/bd/toc.htm.

CCAMLR-XXI/BG/13 2002: The role of CCAMLR. Delegation of Australia, CCAMLR Hobart, Australia: 3 pp.

Cochrane, K.L. \& Doulman, D.J. 2005: The rising tide of fisheries instruments and the struggle to keep afloat. Philosophical Transactions of the Royal Society B 360: 77-94.

COFI 2005: The 2005 Rome Declaration on Illegal, Unreported and Unregulated Fishing. FAO, Rome. http://www.fao. org/docrep/meeting/009/j5030e.htm.

Constable, A.J. 2002: CCAMLR ecosystem monitoring and management: Future work. CCAMLR Science 9: 233-256.

Constable, A.J. 2006: International implementation of the ecosysten approach to achieve conservation of Antarctic marine living resources. Presentation to UNICOPLOS 7: 15 pp. http://www.un.org/Depts/los/consultative_process/ documents/7 constable.pdf

Constable, A.J., de la Mare, W.K., Agnew, D.J., Everson, I. \& Miller, D.G.M. 2000: Managing fisheries to conserve the Antarctic marine ecosystem: Practical implementation of the Convention on the Conservation of Antarctic Marine Living Resources. ICES Journal of Marine Science 57: 778-791.

Croxall, J.P. 1990: Guest editorial: Impact of incidental mortality on Antarctic marine vertebrates. Antarctic Science 2: 1.

de la Mare, W.K., Williams, R. \& Constable, A. 1998: An assessment of the mackerel Icefish (Champsocephalus gunnari) off Heard Island. CCAMLR Science 5: 79-102.

Duhamel, G. 1993: Distribution, abundance et principles characteristiques biologiques des especès de la ZEE des Iles Kerguelen. In Duhamel, D. (ed.): Les rapport des campagnes á la mer. Campagne SKALP 1987 et 1988 aux Iles Kerguelen á bord des navires 'Skif' et 'Kalper'. Linstitut Français pour le Recherche et la Technologie Polaires, Paris. 93-01: 194-251.

Edeson, W., Freestone, D. \& Gudmundsdottir, E. 2001: Legislating for Sustainable Fisheries. A Guide to Implementing the 1993 Compliance Agreement and the 1995 UN Fish Stocks Agreement. The World Bank, Washington D.C.: 151 pp.

Everson, I. 2002: Consideration of major issues in ecosystem monitoring and management. CCAMLR Science 9: 213-232.

FAO 1999: International Plan of Action for Reducing Incidental Catch of Seabirds in Longline Fisheries. FAO, Rome: $78 \mathrm{pp}$. http://www.fao.org/docrep/006/x3170e/x3170e02.htn.

FAO 2001: International Plan of Action to Prevent, Deter and Eliminate Illegal, Unreported and Unregulated Fishing. FAO, Rome: 2-3.

FAO 2003: Fisheries Management: 2. The ecosystem approach to fisheries. FAO Technical Guidelines for Responsible Fisheries 4(2): $112 \mathrm{pp}$.

FAO 2007: The State of World Fisheries and Aquaculture 2006. FAO Fisheries Department, Food and Agriculture Organization of the United Nations, Rome: $162 \mathrm{pp}$.

Fischer, W. \& Hureau, J.C. 1985: FAO species identification sheets for fishery purposes. FAO, Rome, Volume II: $470 \mathrm{pp}$.

Green, J.A. \& Agnew, D.J. 2002: Catch Documentation Scheme to combat Illegal, Unreported and Unregulated fishing: CCAMLR's experiences with the Southern Ocean Toothfish. Ocean Yearbook 16: 171-194.

HSTF 2006: Closing the Net: Stopping Illegal Fishing on the High Sea. Final Report of the Ministerially-led Task Force on IUU Fishing on the High Seas. 112 pp. http:/www. high-seas.org.

Kock, K.H. 1992: Antarctic Fish and Fisheries. Cambridge University Press, Cambridge, New York: 359 pp.

Kock, K.H. 2001: The direct influence of fishing and fisheryrelated activities on non-target species in the Southern Ocean with particular emphasis on longline fishing and its impact on albatrosses and petrels - a review. Reviews in Fish Biology and Fisheries 11: 31-56.

Kock, K.H., Duhamel, G. \& Hureau, J.C. 1985: Biology and status of exploited Antarctic fish stocks: A review. BIOMASS Scientific Series 6: 143 pp.

Larson, K. 2000: Fishing for a compatible solution: Are Toothfish conservation and trade measures working? Environmental Lauyer 7: 123-158.

Miller, D.G.M. 1991: Exploitation of Antarctic marine living resources: A brief history and a possible approach to managing the krill fishery. South African Journal of Marine Science 10: 321-339.

Miller, D.G.M. 2000: The Southern Ocean: A global view. Ocean Yearbook 14: 468-513.

Miller, D.G.M. 2002: Antarctic krill and ecosystem management: From Seattle to Sienna. CCAMLR Science 9: 175-212.

Miller, D.G.M., Sabourenkov, E.N. \& Ramm, D.C. 2004: Managing Antarctic marine living resources: The CCAMLR approach. International Journal of Marine and Coastal Law 19(3): 317-363

Molenaar, E.J. 2001: CCAMLR and Southern Ocean fisheries. International Journal of Marine and Coastal Law 13: 465-499

MRAG 2005: Review of Impacts of Illegal, Unreported and Unregulated Fishing on Developing Countries. Synthesis Report. MRAG, Imperial College, London. 16 pp. http://www2.dfid.gov.uk/pubs/files/illegal-fishing-mragsynthesis-report.pdf.

Oritz, P. 2005: An Overview of the U.S. Lacey Act Amendments of 1981 and a Proposal for a Model Port State Fisheries Information Act. Paper Prepared for HSTF: 40 pp. http:// www.high-seas.org/docs/Lacey_Act_Paper.pdf

Pauly, D., Christensen, V., Guenette, S., Pitcher, T.J., Sumaila, U.R., Walters, C.J., Watson, R. \& Zeller, D. 2002: Towards sustainability in world fisheries. Nature $\mathbf{4 1 8}$ : 689-695.

Rayfuse, R. 1998: Enforcement of high seas fisheries agreements: Observation and inspection under the Convention on the Conservation of Antarctic Marine Living Resources. International Journal of Marine and Coastal Law 13: 579-605.

Sabourenkov, E.N. \& Miller, D.G.M. 2004: The management of transboundary stocks of Toothfish, Dissostichus spp., under the Convention on the Conservation of Antarctic Marine Living Resources. In Payne, A.I.L., O'Brien, C.M. $\&$ Rogers, S.I. (eds): Management of Shared Fish Stocks. Blackwell, Oxford: 68-94

SC-CAMLR 1989: Report of the Eighth Meeting of the Scientific Committee (SC-CAMLR-VIII). CCAMLR, Hobart, Australia: $354 \mathrm{pp}$.

SC-CAMLR 1990: Report of the Ninth Meeting of the Scientific Committee (SC-CAMLR-IX). CCAMLR, Hobart, Australia: 345 pp.

SC-CAMLR 2000: Report of the Nineteenth Meeting of the Scientific Committee (SC-CAMLR-XIX). CCAMLR, Hobart, Australia: 518 pp.

Small, C. 2005: Regional Fisheries Management Organisations: Their Duties and Performance in Reducing Bycatch of Albatrosses and Other Species. Birdlife International, Cambridge, United Kingdom: 103 pp. http://www.birdlife.org/action/ science/species/seabirds/rfmo_report.pdf.

United Nations 1998: International Fisheries Instruments with Index. Division for Ocean Affairs and the Law of the Sea Office of Legal Affairs, United Nations, New York: 110 pp.

United Nations 2006: Sustainable fisheries, including through the 1995 Agreement for the Implementation of the Provisions of the United Nations Convention on the Law of the Sea of 10 December 1982 relating to the Conservation and Management of Straddling Fish Stock and Highly Migratory Fish Stocks, and related instruments. United Nations General Assembly Resolution 60/31: $18 \mathrm{pp}$. 
Vidas, D. 2004: IUU Fishing or IUU Operations? Some observations on diagnosis and current treatment. In Caron, D.D. \& Scheiber, H.N. (eds): Bringing Law to Ocean Waters. Kininklijke Brill NV, Netherlands: 1-20.

Williams, R. 1995: A new fishery for D. eleginoides at Macquarie Island. CCAMLR, Hobart Australia: WG-FSA-95/6, 19 pp. (Mimeograph)

Williams, R. \& de la Mare, W.K. 1995: Fish distribution and biomass in the Heard Island Zone (Division 58.5.2). CCAMLR Science 2: 1-20.
Willock, A. \& Lack, M. 2006: Follow the Leader: Learning from Experience and Best Practice in Regional Fisheries Management Organizations. WWF International \& Traffic International: $55 \mathrm{pp}$.

(accepted 30 July 2007)

\section{APPENDIX 1 \\ Acronyms referred to in this paper}

\begin{tabular}{ll}
\hline ATS & Antarctic Treaty System \\
CAMLR Convention & Convention on the Conservation of Antarctic Marine Living Resources \\
CCAMLR & Commission for the Conservation of Antarctic Marine Living Resources \\
CDS & Catch Documentation Scheme \\
CEMP & CCAMLR Ecosystem Monitoring Programme \\
CITES & Convention on International Trade in Endangered Species \\
CM & Conservation Measure(s) \\
COFI & Committee for Fisheries \\
EEZ & Exclusive Economic Zone \\
FAO & Food and Agricultural Organisation of the United Nations \\
EAF & Ecosystem-Based Approach to Fisheries \\
HSTF & Inter-Ministerial Taskforce on IUU Fishing \\
IPOA & International Plan of Action \\
IUU & Illegal, Unreported and Unregulated \\
LOS Convention & 1982 United Nations Convention on the Law of the Sea \\
MCS & Monitoring, Control and Surveillance \\
RFMO & Regional Fisheries Management Organisation \\
SCAF & Standing Committee on Administration and Finance \\
SCIC & Standing Committee for Implementation and Compliance \\
SSMU & Small-Scale Management Unit(s) \\
SSRU & Small-Scale Research Unit(s) \\
UNCED & 1992 United Nations Conference on Environment and Development \\
UNFSA & 1995 United Nations Fish Stocks Agreement \\
URF & Unified Regulatory Framework \\
WG-EMM & Working Group for Ecosystem Monitoring and Management \\
WG-FSA & Working Group for Fish Stock Assessment \\
WG-IMAF & Working Group on Incidental Mortality Associated with Fishing \\
WSSD & World Summit on Sustainable Development \\
\hline & \\
\hline &
\end{tabular}

